\title{
Annelerinin Ev İçi ve Ev Dışı Rollerine Yönelik Okul Öncesi Çocukların Görüşlerinin Toplumsal Cinsiyet Açısından İncelenmesi
}

\section{Analysis of the Views of Preschool Children Regarding Their Mothers' Roles Inside and Outside Home in Terms of Social Gender}

Gizem ÖZER, Sorumlu Yazar, Dr. Öğr. Üyesi.

Zonguldak Bülent Ecevit Üniversitesi, Ereğli Eğitim Fakültesi, Türkiye.

gizemozer@beun.edu.tr

http://orcid.org/0000-0002-3560-3632

Pembe Buse KESER, Öğretmen.

T.C. Milli Eğitim Bakanlığı, Türkiye.

buseksr10@gmail.com

http://orcid.org/0000-0003-4500-8711

\section{ISSN: 1303-880X \\ e-ISSN: 2667-7504 \\ http://ded.dem.org.tr}

Makale Türü / Article Type:

Araştırma Makalesi / Research Article

Geliş Tarihi / Received Date: 25.01.2020

Kabul Tarihi / Accepted Date: 07.05.2020

Yayın Tarihi / Published Date: 25.06.2020

Tr/En: $\operatorname{Tr}$

Intihal / Plagiarism: Bu makale, en az iki hakem tarafindan incelendi ve intihal içermediği teyit edildi. / This article has been reviewed by at least two referees and scanned via a plagiarism software.
Atıf/Citation: Özer, G. \& Keser, P.B. (2020). Annelerinin ev içi ve ev dişı rollerine yönelik okul öncesi çocukların görüşlerinin toplumsal cinsiyet açısından incelenmesi. Değerler Eğitimi Dergisi, 18 (39), s. 377-413. https://doi.org/10.34234/ded.679593 
Öz: Toplumsal cinsiyete yönelik yapılan pek çok araştırmada, ev içindeki sorumluluklarda kadın ve erkek eşitliğinin sağlanamadığı görülmektedir. Bu araştırmada, okul öncesi dönemdeki 4-6 yaş arası çocukların annelerinin ev içi ve ev dışı rollerine yönelik görüşlerinin toplumsal cinsiyet açısından incelenmesi amaçlanmıştır. Araştırmada nitel araştırma desenlerinden durum çalışması kullanılmıştır. Çocuklara iki ayrı soru ("Annen evde neler yapar?" ve "Annen d1şarıda neler yapar?") sorulmuş ve bu sorularla ile ilgili iki ayrı resim çizmeleri ve bu resimleri araştırmacıya anlatmaları istenmiştir. Veriler, çocuklarla birebir görüşme yapılarak ve araştırmacının görüşme süresince aldığ 1 yazılı notlar ile toplanmıştır. Çalışma grubunun seçiminde tipik durum ve kolay ulaşılabilir örnekleme metotları kullanılmıştır. Araştırmanın çalışma grubunu Karadeniz Ereğli ilçesinde anaokuluna devam eden; üçü dört yaşında, on beşi beş yaşında ve ikisi altı yaşında olmak üzere 20 çocuk oluşturmaktadır. Çalışma grubunu oluşturan çocukların on tanesi erkek ve on tanesi de kız çocuktur. Veriler içerik analizi yöntemiyle analiz edilmiş ve araştırmacılar tarafından kodlanarak kod, kategori ve temalara ulaşılmıştır. Araştırma sonucunda elde edilen temalar; annelerinin evde neler yaptığına yönelik; "ev düzeni”, “diğerlerine ilgi” ve "kendine ilgi”, dışarıda neler yaptığına yönelik olarak ise; "olumlu kendine ilgi”, "sorumluluk", "çocuklara ilgi”, "dış düzen" ve "olumsuz kendine ilgi”" şeklindedir. Araştırma sonucunda ailelerin çocuklarına toplumsal cinsiyet açısından olumlu model olmaları önerilmiştir.

Anahtar Kelimeler: Toplumsal cinsiyet, Toplumsal cinsiyet rolleri, Toplumsal cinsiyet kalıp yargıları, Okulöncesi dönem.

$\&$

Abstract: In many studies on social gender, it is observed that equality between men and women cannot be attained in terms of household chores. In this study, it is aimed to analyse the views of children between 4 and 6 years of age in preschool period regarding their mother's role inside and outside home in terms of social gender. The case study method which is one of the qualitative research design has been used in the study. The children were asked two different questions ("What does your mother do at home?" and "What does your mother do outside?") and they were requested to draw two distinct pictures related to these questions and explain these pictures to the researcher. The data was collected in one-to-one interviews with the children and in written notes taken by the researcher during the interview. Typical case and easily accessible sampling methods were used in the selection of the study group. The study group consists 
of 20 children who attend kindergarten in the Karadeniz Ereğli Township, three of whom are four years old, fifteen of whom are five years old and two of whom are six years old. The study group consists of ten boys and ten girls. The data was analyzed with content analysis method, coded by researchers and it is converted to codes, categories and themes. Accordingly, the themes attained from the study in relation to what children's mothers do at home are "keep house", "care to others" and "care to herself", and in relation to what they do outside are "positive care to herself", "responsibility", "care to children", "external order" and "negative care to herself". As a result of the research, it was suggested that families be positive models for their children in terms of social gender.

Keywords: Social gender, Social gender roles, Social gender stereotypes, Preschool period.

(The Extended Abstract is at the end of the article)

\section{Giriş}

Toplumsallaşma süreci ile edinilen kadın ve erkek olmaya dair özellikler toplumsal cinsiyet olarak ifade edilmektedir (Altınova ve Duyan, 2013). Toplumsal cinsiyet, cinsiyet kavramından toplumsal yönü ile ayrılmaktadır, cinsiyet biyolojik yönü, toplumsal cinsiyet ise toplumsal yönü vurgulamaktadır. Toplumsal cinsiyet toplumda, toplumsallaşma süreci içinde sosyalleşme ile kazanılır. Toplumsal cinsiyet, biyolojik cinsiyete uyumlu olarak toplum içerisinde şekillenir ve kültüre, toplumdan topluma, çağa göre değişkenlik gösterebilir (Yağan Güder, 2014). Toplumsal cinsiyetin kavramsal olarak gelişimi ile beraber bu kavrama ilişkin kalıp yargılar da oluşmaya başlamıştır. Kalıp yargılar çeşitli davranışların kadın ve erkeğe uygunluğuna dair inançlar olarak tanımlanabilir (Güney, 2012). Fakat bu kalıp yargıların oluşumu ve genel gidişatı izlendiğinde kadınlar aleyhine bir ilerleyiş olduğu sezilmektedir. Özellikle ülkemizde kadının, aile içi yaşantısında "mutlaka yapması gereken işler/davranışlar" gibi bir takım kabul edilmiş toplumsal cinsiyet kalıp yargılarının olduğu fark edilebilir. Ailenin bir bireyi olan çocukların gözlemleri bu konuda önemli ipuçları verebilir. Bu araştırmada okul öncesi dönem çocuklarının görüşleri açısından annelerinin ev içinde ve ev dışında yaptıkları etkinliklerin incelenmesi ve bu etkinliklerin toplumsal cinsiyet kalıp yargıları doğrultusunda olup olmadığının yorumlanması amaçlanmaktadır. 
Toplumsal cinsiyet kavramına yönelik yapılan araştırmalar özellikle son yıllarda artış göstermeye başlamıştır. İncelenen araştırmaların pek çoğunda toplumsal cinsiyet kalıp yargılarına yönelik hem çocuklarda hem de yetişkinlerde eğilimlerin olduğu görülmüştür. Örneğin; Güney (2012), 5-6 yaş çocukları ile yaptığ 1 araştırmasında çocukların oyuncak tercihlerinde cinsiyetçi olma ve bu durumu anne babanın etkileyip etkilemediğini araştırmıştır. Buna göre çocukların neredeyse tamamının iki oyuncak setini de (cinsiyet kalıp yargı açısından kzzlara atfedilen mutfak seti ve erkeklere atfedilen tamir aletleri) sevdikleri fakat oyun oynama tercihi söz konusu olduğunda kızların çoğunluğunun mutfak setini, erkeklerin ise neredeyse tamamının tamir aletlerini seçtikleri bulunmuştur. Aynı zamanda anne babaların da çocuklarının kendi cinsiyetlerine yönelik olarak atfedilen oyuncaklara yönelmelerini destekledikleri görülmüştür. Yapılan başka bir araştırmada, okul öncesi dönem çocuklarının anne babalarına yönelik algıları cinsiyet rolleri açısından incelenmiştir (Bağçeli Kahraman ve Arabacıŏ̆lu, 2018). Bu araştırmanın sonuçlarına göre; çocukların çoğunluğunun annelerinin neler yaptığına yönelik olarak yöneltilen soruya "yemek yapar”, bunu takip eden sırada ise "temizlik yapar" şeklinde cevap verdikleri görülmüştür. Bununla beraber aynı soru babaları açısından sorulduğunda ise "işe gider" ve bunu takip eden sırada ise "para kazanır" şeklinde cevap verdikleri belirtilmiştir. Ev içi yaşantı söz konusu olduğunda annelerin evin yemek ve temizlik gibi yaşamsal etkinliklerinin çoğunu tek başına yapmakta olduklarını, çocuklarının görüşlerine göre destekleyen başka araştırmalar da bulunmaktadır. Akar ve Aksoy'un (2018), araştırmasında çocukların anne babalarına yönelik algılarının toplumsal cinsiyet açısından incelenmesi amaçlanmıştır. Bu araştırmanın sonuçlarına göre; örneklemde yer alan anasınıfı ve dördüncü sınıf çocuklarının annelerini "yemek-temizlik yapan" ve "bize bakan kişi” olarak tanımladıkları, evde neler yaptıklarına yönelik olarak da "temizlik yapar" ve "yemek yapar" şeklinde ifadede bulundukları bulunmuştur. Babalar ise bu araştırmada "işe giden" ve evde "dinlenir-uyur" ve "televizyon izler" bulgularıyla yer almışlardır. Belirtilen bu araştırmaların bulguları göz önüne alındığında, ailelerin çoğunluğunda anne ve baba arasında ev işlerinin yapımında eşitlikçiliğe dayanan bir uygulamanın yer almadığı söylenebilir. Buna ek olarak işe gitmek söz konusu olduğunda çocukların bunu babaları ile özdeşleştirdiklerine dair görüşleri, yapılan başka bir araştırmada da desteklenmiştir. Bu araştırmada çocukların babalarını işe gitme işlevi ile, anneleri ise bakım verme işlevi ile tanımladıkları görülmüştür (Aytekin, Artan, Bencik Kangal, Çalışandemir ve Özkızıklı, 2016). 
Aile içinde kadına dair bu durumun kalıp yargı olarak oldukça genelleşmiş olduğunu düşünebiliriz. Bu duruma yönelik çocukların kendi ifadelerinin gözlemlendiği ve çocukların okudukları kitapların ve izledikleri çizgi filmlerin içinde geçen kavramların incelendiği araştırmalar da mevcuttur. Kitaplara ve çizgi filmlere yönelik olarak; 4-6 yaş çocuk kitaplarındaki kadın kahramanların mesleksel analizlerinin yapıldığı bir araştırmada kadın karakterlerin çoğunluğunun ev hanımı olarak tasvir edildiği, hikâyelerde annelerin genellikle yemek yaptığı, çocuklara baktığı, çamaşırları yıkayıp astı̆̆ı, evdeki temizliği yaptı̆̆1 görülmektedir (Dilek, 2014). Kitaplara yönelik olarak; Gürşimşek ve Günay Doğan'ın (2005) araştırmasında da cinsiyet kalıp yargısal durumların okul öncesi dönem çocuk kitaplarında en belirgin şekilde giysiler ve fiziksel özellikler ile belirtildiği, yoğunluklu olarak kadınların etek, elbise, erkeklerin ise pantolon, gömlek şeklinde kıyafetler giydiği görülmüş; renk bağlamında ise kadınlarda pembe, yeşil, erkeklerde mavi ve siyah rengin kullanıldığ 1 bulunmuştur. Çizgi filmlere yönelik olarak ise, "Okul öncesi dönem çocuklarının izledikleri çizgi filmlerin toplumsal cinsiyet kalıp yargıları açısından incelenmesi: Niloya Örneği” isimli yapılan araştırmada, anne rolünün daha çok ev içerisinde olduğu, baba rolünün çizgi filmde daha az yer aldığı ve çoğunlukla araba sürme, odun kırma gibi geleneksel faaliyetlerde bulunduğu gözlenmiştir (Yağan Güder, Ay, Saray ve Kılıç, 2017).

Çocukların kalıp yargısal ifadelerini içeren bir araştırmada; Yağan Güder ve Güler Yıldız (2016), çocukların kalıp yargısal görüş belirtmelerinde, annelerinin ev hanımı olması, annelerin şiddete uğraması ve çocukların buna tanıklık etmesi ve bunlara ek olarak aile içi sorumlulukların geleneksel bir dağılımının olması etkenlerini bulmuşlardır. Aynı araştırmada yer alan Koray isimli bir erkek çocuğunun anneannesinin çocuk ile ilgili ifadesi dikkat çekicidir; "Koray'a iş yaptıramıyom. Koray ben mi yapcam diyo? Benim görevim değil. Anneanne diyo sen bizim evin hizmetçisisin. Sen yapcan diyo bana" (Yağan Güder ve Güler Yıldız, 2016). Çocukların kalıp yargısal görüşleri ile ilgili yapılan bir başka araştırmada çocukların mesleklere dair geleneksel/kalıp yargısal ifadelerde bulundukları (örneğin terzilerin hep kadın olabileceğini, pilotların hep erkek olabileceğini belirtmeleri gibi) fakat annesi çalışan çocukların, çalışmayanlara göre daha az kalıp yargı ifadesi kullandıkları bulunmuştur (Karabekmez, Yıldırım, Özyılmaz Akamca, Ellez ve Bulut Üner, 2018). Bu belirtilen araştırmalardaki bazı çocuklarda da görüldüğü üzere toplumsal cinsiyet kalıp yargıları okul öncesi çocuklarında dahi görülebilmektedir. 
Aile içinde kadının rolü söz konusu olduğunda neden akla ilk olarak çalışmasından ziyade ev işine yönelik davranışları gelmektedir? Dedeoğlu (2000), her toplumda cinsler arasında kadını, çocuk bakımı ve ev işleri gibi faaliyetlerin yapıldığı alana sınırlayan bir görev dağılımının kabul gördüğünü, bunun da kadın işgücü istihdamını etkilediğini belirtmiştir. Çarkoğlu ve Kalaycıŏlu'na göre (2013), ülkemizdeki aile içi demokratik ilişkilerin gelişimi geridedir ve aile içinde kadınların temel görevinin çocuk yetiştirmek olduğu görüşü oldukça yaygındır. Günay ve Bener (2011), geleneksel bakış açısına göre ailede işler ve sorumlulukların cinsiyet gözetilerek eşitlikçi olmayan şekilde paylaşıldığını ama bu durumun, eğitim düzeyi daha yüksek, kadınların çalıştı̆̆ı, anlaşarak evlenmiş olan kadın ve erkeği içeren ailelerde daha eşitlikçi yönde değişmekte olduğunu belirtmişlerdir. Çocukların ister geleneksel rolleri, ister modern kadın ve erkek rollerini barındıran aile yapısının içinde önemli bir unsur oldukları düşünülebilir. Ailenin bir bireyi olan çocukların aile içinde kadının, yani annelerinin rollerine ilişkin görüşleri önemli görülmektedir. Bu sebeple bu araştırmada, çocukların görüşlerine göre annelerinin ev içinde ve ev dışında yaptıkları etkinlikler incelenerek, elde edilen verilerin toplumsal cinsiyet açısından incelenmesi ve yorumlanması amaçlanmaktadır. Alt araştırma soruları ise "annelerin ev içinde neler yaptıkları" ve "ev dışında neler yaptıkları" şeklinde belirlenmiştir.

\section{Yöntem}

Araştırmada, nitel araştırma yöntemi kullanılmıştır. Nitel araştırma, alg1 ve olayların kendi ortamında bütüncül ve gerçekçi bir yapıda ortaya koyulmasını sağlayan araştırma yöntemidir (Yıldırım ve Şimşek, 2016). Nitel araştırmalarda; gözlem, görüşme, doküman analizi gibi veri toplama yöntemleri kullanılmaktadır. Bu araştırmada nitel araştırma yöntemlerinden durum çalışması kullanılmış, çocuklarla yarı yapılandırılmış mülakatlar gerçekleştirilmiş̧ir. Durum çalışması araştırma deseni, araştırmacının bir durumu, sıklıkla bir programı, olay1, eylemi, süreci ya da bir veya daha fazla bireyi derinlemesine ve detay11 incelediği bir araştırma desenidir (Creswell ve Creswell, 2018; Creswell, 2016). Durum çalışması araştırmalarının odaklandıkları nokta, anlatı araştırmalarındaki gibi bireyler ve onların hikâyelerinin incelenmesinden ziyade, konu üzerine odaklanarak tek bir durum yoluyla bu konunun anlaşılması üzerinedir (Creswell, Hanson, Clark Plano ve Morales, 2007). Bu araştırmada durum çalışması desenlerinden bütüncül çoklu durum deseni kullanılmıştır. Bu desende birden fazla kendi başına bütüncül olarak algılanabilecek durum söz konusudur; her bir durum kendi içinde bütüncül olarak ele alınır ve daha sonra birbirleriyle 
karşılaştırılır (Yıldırım ve Şimşek, 2016). Araştırmadaki katılımcı sayısının bir kişiden çok oluşu ve her birinin ayrı ayrı inceleniyor ve yorumlanıyor olması sebebiyle bu araştırmanın bütüncül çoklu durum deseni olarak desenlenmesi planlanmıştır. Elde edilen verilerin analizinde içerik analizi kullanılmıştır. İçerik analizi; veriler arasında yer alan anlamlı bölümlere isim verilmesi sürecini içermektedir; birbirine benzer nitelikte olan veriler belirli kavram ve temalar doğrultusunda bir araya getirilir ve yorumlanır (Yıldırım ve Şimşek, 2016).

\section{Çalışma Grubu}

Nicel araştırmalarda birincil amaç genellemedir. Nitel araştırmalarda ise felsefi ve kuramsal temellerinden dolayı birincil amaç olarak genelleme yapmak söz konusu değildir. Olguları parçalara ayırmadan bir bütün olarak ele alır ve genellikle evrenin bütününü işe koşarlar. Bu sebeple örneklemeye ihtiyaç duyulmaz (Yıldırım ve Şimşek, 2016). Araştırmada, nitel araştırma doğasına uygun olan amaçlı örnekleme yöntemi kullanılmıştır. Amaçlı örnekleme tekniklerinden ise tipik durum örneklemesi ve kolay ulaşılabilir örnekleme yöntemi kullanılmıştır. Tipik durum örneklemesinde amaç, ortalama durumları çalışarak belirli bir alan hakkında fikir sahibi olmaktır, kolay ulaş1labilir örneklemede ise yakın olan ve erişilmesi kolay olan durum seçilir (Yıldırım ve Şimşek, 2016). Çalışma grubu 2018-2019 Güz eğitim öğretim yıll, Zonguldak ili Karadeniz Ereğli ilçesinde yer alan bir ilköğretim okulunun anasınıfındaki çocuklardır. Okul Ereğli ilçesinin Kepez bölgesinde yer almaktadır. Bu bölge orta sosyo-ekonomik düzeyde ailelerin ikamet ettiği bir bölgedir. Araştırmanın çalışma grubunu; üçü dört yaşında, on beşi beş yaşında ve ikisi altı yaşında olmak üzere 20 çocuk oluşturmaktadır. Çalışma grubunu oluşturan çocukların on tanesi erkek ve on tanesi de kız çocuktur.

\section{Veri Toplama Süreci}

Veriler yarı yapılandırılmış görüşme soruları ile toplanmıştır. Araştırmacı çocuklara "Annen evde neler yapar?" ve "Annen dışarıda neler yapar?" şeklinde iki soru sormuş, çocukların bu sorulara dair iki resim çizmelerini ve çizdikleri bu resimleri anlatmalarını istemiştir. Araştırmacı resim çizimi sürecinde ve resim çizimi tamamlandığında çocuklarla birebir ve yüz yüze görüşmüş ve resimlerini anlatmalarını istemiştir. Araştırmacı çocukların ifadelerini yazarak kaydetmiştir. Çocukların çizdikleri resimler herhangi bir resim analizine tabi tutulmamış olup, elde edilen sözel verileri desteklemek üzere görsel olarak araş- 
tırmada yer almıştır. Araştırmacı tarafından kayda geçirilen çocukların sözel ifadeleri, analiz verisini oluşturmuştur.

\section{Verilerin Analizi}

Toplanan veriler içerik analizi yöntemiyle analiz edilmiştir. İçerik analizinde asıl gaye verileri açıklayan kavramlarla, ilişkilere ulaşmaktır. Yapılan temel işlem ise benzeyen verileri belli kavram ve temalar doğrultusunda bir araya getirmek, düzenlemek ve okuyucunun anlayabileceği bir şekilde yorumlayarak sunmaktır (Yıldırım ve Şimşek, 2016). Araştırmacı çocukların çizdikleri resimler doğrultusunda yaptığı görüşmelerden elde ettiği verileri öncelikle kodlamış, sonrasında bu kodlardan bazı kategori ve temalara ulaşmıştır.

Veriler iki bölüm halinde analiz edilmiştir. İlk olarak "Annen evde neler yapar?" durumundaki görüşme kayıtları, daha sonra "Annen dışarıda neler yapar?" durumundaki görüşme kayıtları analiz edilmiştir. Kod, kategori ve temalar içerik analizi yaklaşımına uygun olarak daha önceden belirlenmiş değildir. Literatürden elde edilen herhangi bir kod, kategori veya tema kullanılmamış, araştırmacılar tarafından elde edilen verilerin tekrarlı okunmaları ve birbirleri ile ilişkilendirilmeleri doğrultusunda kod, kategori ve sonrasında temalara ulaşılmıştır. Araştırmac1 çalışma grubundaki her çocuktan topladığ verileri bilgisayar ortamında yazılı hale dönüştürmüş, ardından her veriyi tekrar tekrar okuyarak ilk kodlara ulaşmıştır. Elde edilen kodlar incelendiğinde ortak-benzer ifadelerin daha sınırlandırılmış kategori çatıları altında toplanabileceği görülmüştür. Bu kategorilerden de daha özet ifade şekilleri olan temalara ulaşılmıştır. Ulaşılan temalar ve kategoriler, uzman görüşü amaciyla okul öncesi eğitim bölümünde görev yapan ve nitel araştırmalar yapmış olan bir öğretim üyesinin görüşleri alınarak tekrar incelenmiş, yeniden okunarak kodlanmış ve düzenlenmiştir.

Elde edilen kod, kategori ve temalara yönelik olarak frekans bilgilerine de yer verilmiştir. Bu frekans bilgileri ile herhangi bir genelleme yoluna gidilmemiştir. Burada birinci amaç okuyucuya kod, kategori ve temalar arasındaki görsel dağ1lımı göstermek, ikinci amaç güvenirliği arttırmak, üçüncü amaç ise okuyucunun ortaya çıan tema ve kategoriler arasında karşılaştırmalar yapabilmesini sağlamaktır. Nitel verinin doğal yapısı, niceliksel bilgiler ile genellemeler yapmaya ve değişkenler arası ilişki aramaya zaten uygunluk göstermemektedir (Yıldırım ve Şimşek, 2016). 


\section{Geçerlik ve Güvenirlik Önlemleri}

Bu bölümde araştırmanın geçerlik ve güvenirlik çalışmalarına yönelik alınan önlemlere sırası ile yer verilmiştir. Nitel araştırmalardaki geçerlik ve güvenirlik önlemleri nicel araştırmalardan oldukça farklıdır (Creswell, 2016; Yıldırım ve Şimşek, 2016). Nitel araştırmalarda geçerlik ve güvenirliği sağlamada kullanılan yöntemlerden bir tanesi üçgenlemedir. Üçgenleme, kaynaklardan delillerin incelenmesiyle bilginin farklı veri kaynaklarını gösterir ve temaların tutarlı bir doğrulamasını inşa etmede kullanılır (Creswell, 2016). Çeşitleme olarak da isimlendirilen üçgenleme teknikleri; veri kaynakları, yöntem ve araştırmacı çeşitlemesi olarak kendi içinde alt başlıklara ayrılabilir (Yıldırım ve Şimşek, 2016). Bu araştırmada veri kaynakları ve yöntem çeşitlemesi kullanılmıştır. Veri kaynaklarının çeşitlendirilmesi farklı özelliklere sahip katılımcıların araştırmaya dâhil edilmesi ile farklı yaşantıların ortaya konmasını amaçlar (Yıld1rım ve Şimşek, 2016). Farklı yaşantılara sahip çocukların bu araştırmada yer alması veri kaynakları çeşitlendirilmesine katkı sağlamaktadır. Kullanılan diğer üçgenleme tekniği ise yöntem çeşitlemesidir. Bu çeşitleme gözlem, görüşme, dokümanlar gibi pek çok veri kaynağının araştırmada kullanılmasını gerektirir. $\mathrm{Bu}$ araştırmada bu amaçla, çocuklarla yapılan sözel görüşme kayıtlarını desteklemek için çocukların resim çizimleri kullanılmıştır. Geçerlik ve güvenirliği sağlamada bir diğer tavsiye edilen yöntem olan dış denetleyici / uzman görüşü tekniği de bu araştırmada kullanılmıştır. Bunun için nitel araştırmalar konusunda çalışmalar yapmış, Ankara'da büyük bir üniversitede çalışan bir öğretim üyesinin görüşlerine başvurulmuştur. Geçerlik ve güvenirliğe yönelik olarak nitel araştırmalarda doğrudan alıntılar yapmak da iç güvenirlik süreçlerine katkı sağlar (LeCompte ve Goetz, 1982; Akt., Yıldırım ve Şimşek, 2016). Bu araştırmada da çocukların ifadeleri bulgular bölümünde doğrudan söyledikleri sözler şeklinde alıntılar ile sunulmuştur.

\section{Bulgular ve Yorum}

Okul öncesi dönemdeki 4-6 yaş arası çocukların annelerinin ev içi ve ev dışı rollerine yönelik görüşlerinin, toplumsal cinsiyet açısından incelenmesinin amaçlandığ bu araştırmadan elde edilen bulgular bu bölümde belirtilmiştir.

\section{“Annen Evde Neler Yapar?” Bölümüne Yönelik Bulgular (Kodlar)}

Araştırmacı içerik analizi sonucu elde ettiği ilk kodlarda; "Annen evde neler yapar?” bölümüne yönelik olarak; hem kız hem erkek çocuklarda "yemek yapar”, 
“evi toplar”, “yatağı toplar”, "temizlik yapar”, “evi süpürür”, "bulaşık yıkar”, "çamaşır yıkar", "televizyon izler" kodlarına ulaşmıştır. Kız ve erkek çocukların kodlarında ortak olmayanlar ise, kız çocuklarda yukarıda elde edilen kodlara ek olarak; "kediye yemek hazırlar", "el işi yapar", kodlarıdır. Erkek çocukların kızlarla ortak olmayan diğer kodları ise; "evi siler", "oyuncakları toplar", "boyama yapar”, “çizgi film izler” şeklindedir. Bu kodların gösterimi Tablo 1'de yer almaktadır.

İlk elde edilen kodlar incelendiğinde annelerin evde "yemek" ve "temizlik" işlerini yoğunlukla yaptıkları hissedilmektedir. Örneğin "bulaşık yıkar" kodu içerisinde yer alan kız çocuklardan olan A: "Tabakları ylkar, yemekleri yapar, yemekleri doldurur, bulaşıkları yıkar, çamaşır makinası da yapcam” şeklinde cevap vermiş̧tir. Aynı kodda yer alan erkek çocuk KZ: "Yemek pişiriyor, bulaşık temizliyor, temizlik yapıyor yerler kirliyken, duvarları temizliyor, çamaşır yıkıyor" şeklinde cevap vermiştir.

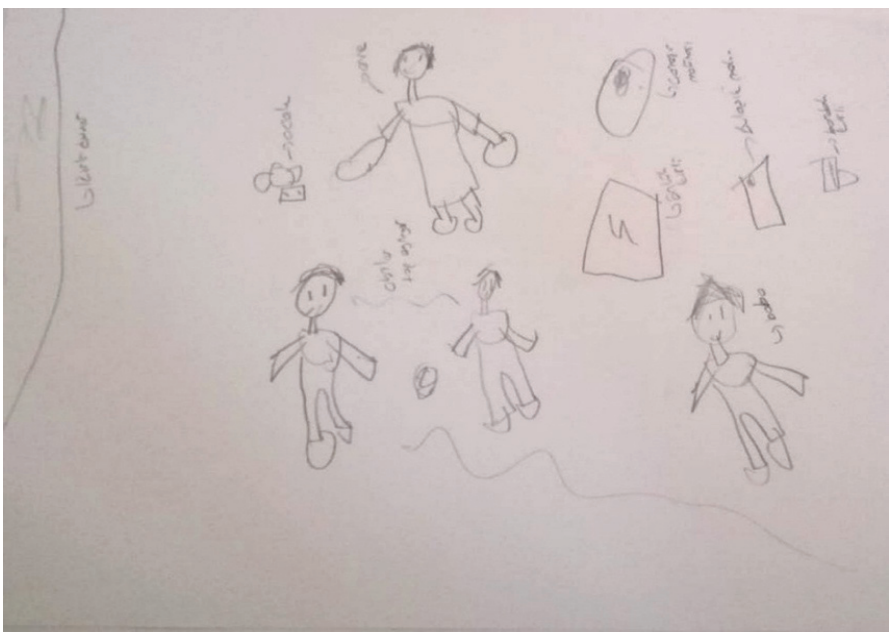

Şekil 1. KZ isimli çocuğun resmi

"Yemek yapar" kodu içerisinde yer alan kız çocuk ZB: "Annem evde yemek yapar. Aygaz.. Annem karşısında. Mutfakta şeyler olur böyle yukarda olan şeyler." ifadelerinde bulunmuştur. Aynı kodda yer alan erkek çocuk AB: "Annem evde yemek yapar. Ben dlşarda oynarken, annem yemek yapar. Burası da kırmızl, hayır pembe. Şuraya da ev çizeyim. Şuraya da güneş. Bahçede oyun oynuyorum. Çorba yapar." 


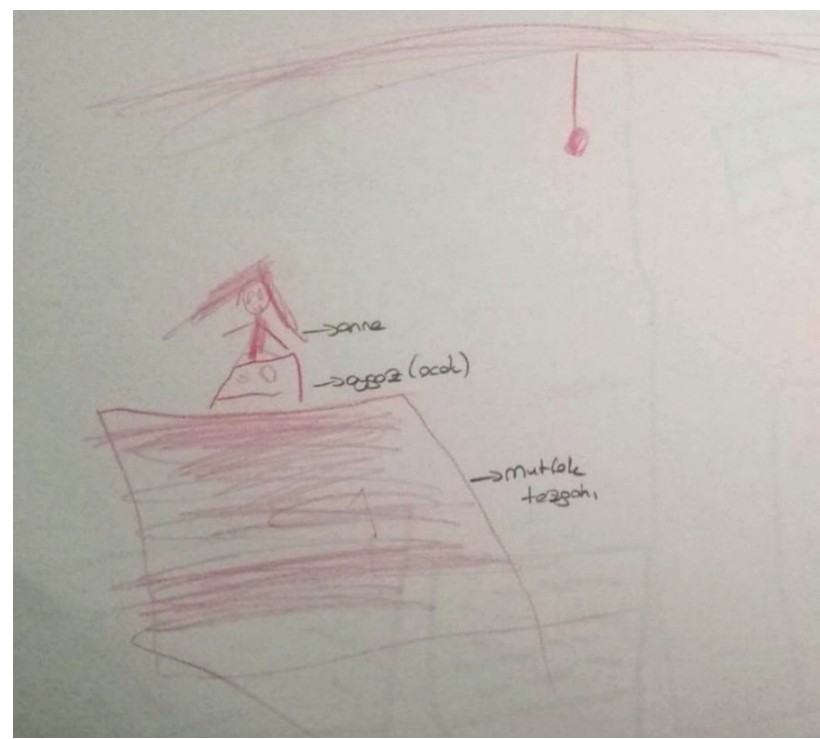

Şekil 2. ZB isimli çocuğun resmi

"Evi toplar" kodu içerisinde yer alan erkek çocuk G: "Ev yapabilirim. Bulaşık yıklyor, bulaşık için musluk. Ortalıkları toplar.” Aynı kodda yer alan kız çocuk Y: "Tabaklart pembe yapıcam. Evi topluyo, temizlik yapıyo. Babam da tv izliyo."

"Televizyon izler" kodu içerisinde yer alan kız çocuk ZB: "Salonda televizyona bakar. Kumanda elinde.” Aynı kodda yer alan erkek çocuk B: "Oturuyor, televizyon izliyor." şeklinde cevap vermiştir.

\begin{tabular}{|c|c|}
\hline Kod & Çocukların Örnek İfadeleri \\
\hline Yemek yapar. & $\begin{array}{l}\text { Kı1z 5y/ AŞ: Mutfak tezgâhı çiziyorum. Çünkü annem evde } \\
\text { yemek yapıyor. }\end{array}$ \\
\hline Temizlik yapar. & K1z 6y/ ES: Evde temizlik yapıyor. \\
\hline Evi toplar. & Erkek 5y/ G: Ortalıklarl toplar. \\
\hline Yatağı toplar. & Kız 5y/ AD: Yatağımızı toplar. \\
\hline Evi süpürür. & $\begin{array}{l}\text { Erkek 5y/ MC: Elektrikli süpürge. Evi süpürüyor şu anda } \\
\text { annem. }\end{array}$ \\
\hline Bulaşık yıkar. & Erkek 4y/ M: Temizlik yapar, bulaşık yapar. \\
\hline Kediye yemek hazırlar. & $\begin{array}{l}\text { Kiz 5y/ AŞ: Kediye yemek hazırlıyo. Annem kediye patates } \\
\text { kuzartıor. }\end{array}$ \\
\hline El işi yapar. & K1z 5y/ B: Bi de oturur el işi yapar. \\
\hline Televizyon izler. & Erkek 5y/ B: Oturuyor, televizyon izliyor. \\
\hline Evi siler. & Erkek 5y/ C: Temizlik yapar, yerleri süpürür, yerleri siler. \\
\hline Çamaşır yıkar. & Erkek 5y/ KZ: Çamaşır yıkıyor. \\
\hline Oyuncakları toplar. & Kız 5y/ Y: Oyuncaklarl düzenliyor. \\
\hline Boyama yapar. & Erkek 4y/ M: Boyama yaptırtr. \\
\hline Çizgi film izler. & Erkek 4y/ M: Çizgi film izler. \\
\hline
\end{tabular}


Çocuk çizimlerinden diğer bazı örnekler şu şekildedir;

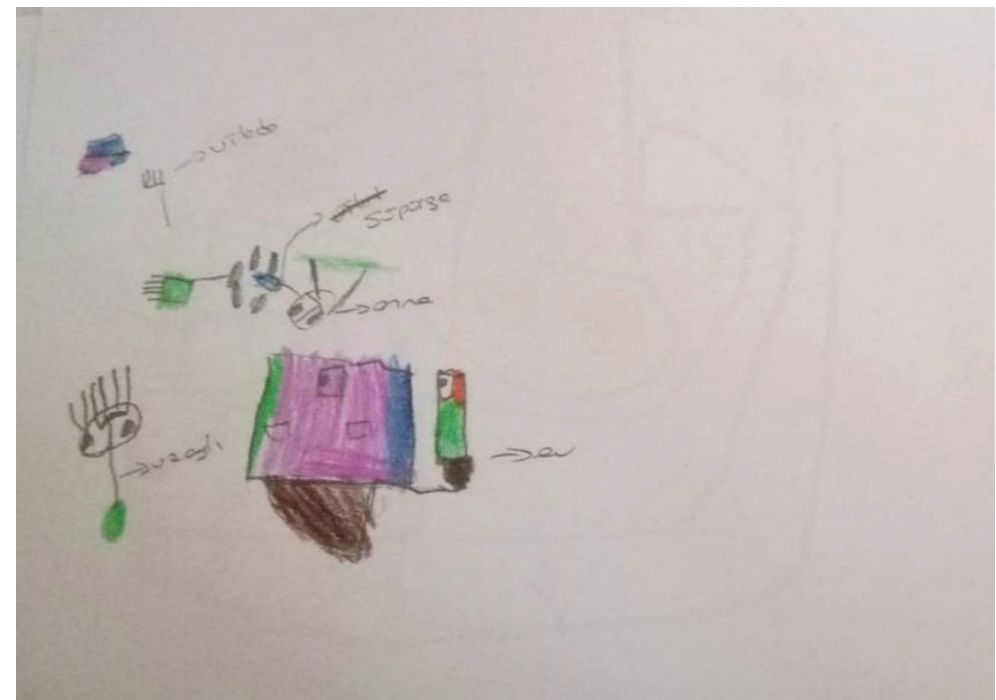

Şekil 3. B isimli çocuğun resmi

B isimli erkek çocuğun resminde yer silme paspası, süpürge gibi ayrıntılar dikkat çekmektedir. Z isimli kız çocuğun resminde ise annesinin elinde tencere vardır. E ve $\mathrm{M}$ isimli kız çocuklarının resmindeki tepsi ve içindeki yemekler, bulaşık, temizlik kovası ve ocak ayrıntıları dikkat çekmektedir.

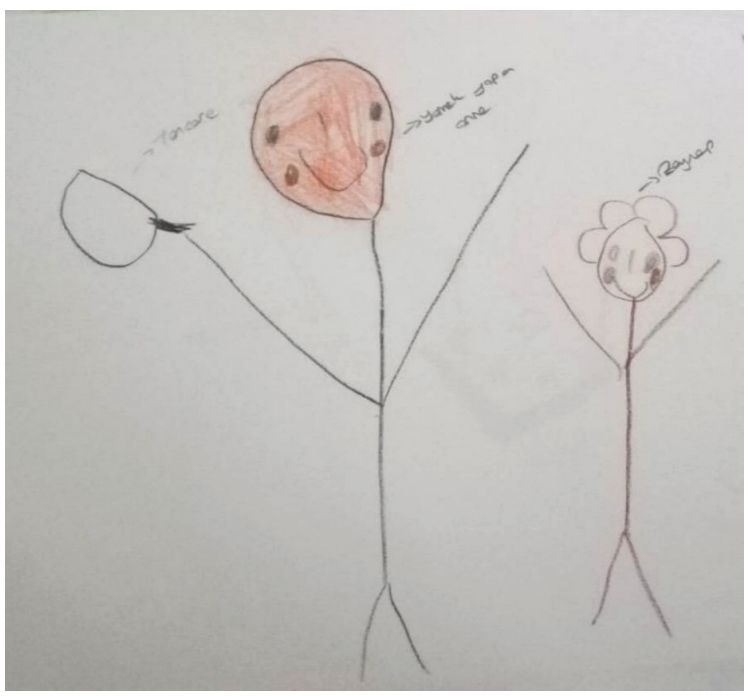

Şekil 4. Z isimli çocuğun resmi 


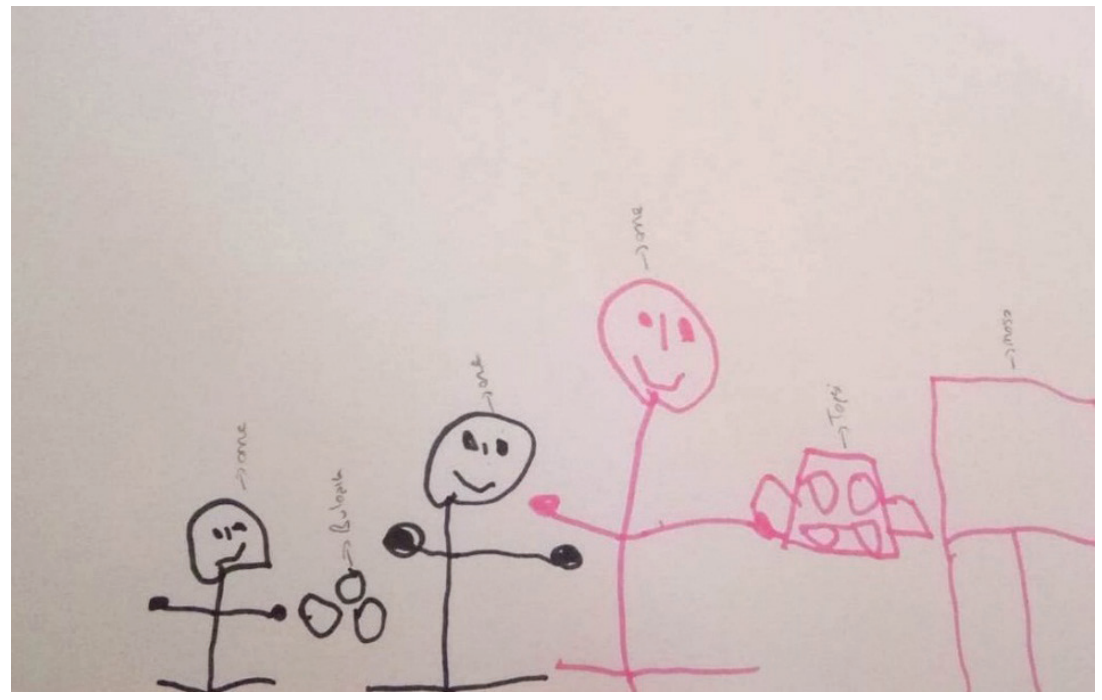

Şekil 5. E isimli çocuğun resmi
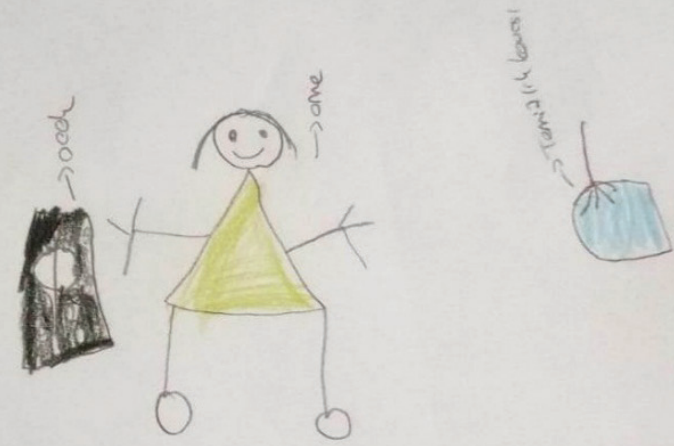

Şekil 6. M isimli çocuğun resmi

\section{“Annen Dişarıda Neler Yapar?” Bölümüne Yönelik Bulgular (Kodlar)}

Araştırmacı içerik analizi sonucu elde ettiği ilk kodlarda; "Annen dışarıda neler yapar" bölümüne yönelik olarak; hem kız hem erkek çocuklarında "hiçbir şey yapmaz”, "pazara gitmek”, “yemek alır”, “oyun oynatır”, "parka götürür”, "gezmeye götürür”, "gezer”, "elbise alır” kodlarına ulaşmıştır. Kız ve erkek çocukların kodlarında ortak olmayanlar ise, kız çocuklarda yukarıda elde edilen 
kodlara ek olarak; "dışarıyı süpürür", "merdiveni temizler", "halı yıkamak", "dışarıyı toplar", "mancarları sular", "işe gider”, "sinemaya gider”, "arkadaşlarıyla vakit geçirir", "arkadaşlarıyla konuşur” kodlarıdır. Erkek çocukların kızlarla ortak olmayan diğer kodları ise; "bahçeyi sular", "okula götürür", "kardan adam yapar", "aşağıda temizlik yapar", "doktora gider", "sohbet eder", “oturur", "misafirliğe gider", "süt alır" şeklindedir. Kodların genel dağılımı Tablo 2 'de gösterilmektedir.

İlk elde edilen kodlar incelendiğinde dışarıda çocuklara bakım ve sosyal aktivite konusunda annelerin aktif olduğu hissedilmektedir. Ama aynı zamanda dışarıda geçirdikleri vakitte de annelerin temizlik yaptıkları çocukların ifadelerinden anlaşılmaktadır. Örneğin "parka götürür” ve "oyun oynatır" kodlarında yer alan kız çocuklardan ES: "Mesela canım sıkıldiğında annem beni parka götürür. Annem canım sıkıldı̆̆ında şey yapar oyun oynarız dışarda. Ama hava güneşliyken." şeklinde cevap vermiştir. ES isimli çocuğun resminde annesinin "dışarıda" çizdiği resmine süpürge çizdiği görülmüştür. Aynı kodlarda yer alan başka bir erkek çocuk M: "Dışarıda birazcık gezerler, beni oyun oynatırlar." şeklinde cevap vermiştir.

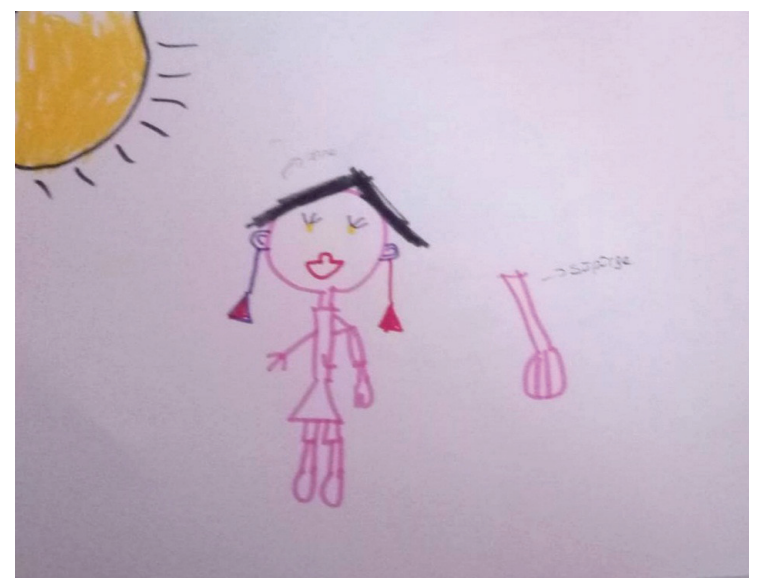

Şekil 7. ES isimli çocuğun resmi

"Dışarıyı toplar" kodunda yer alan kız çocuk Y: "Merdiven de yapcam. Merdiven temizliği yapıyo. Dışarıyı toplamaya gidiyo. Kum yapcam, bi de süpürge." şeklinde kendini ifade etmiştir. 


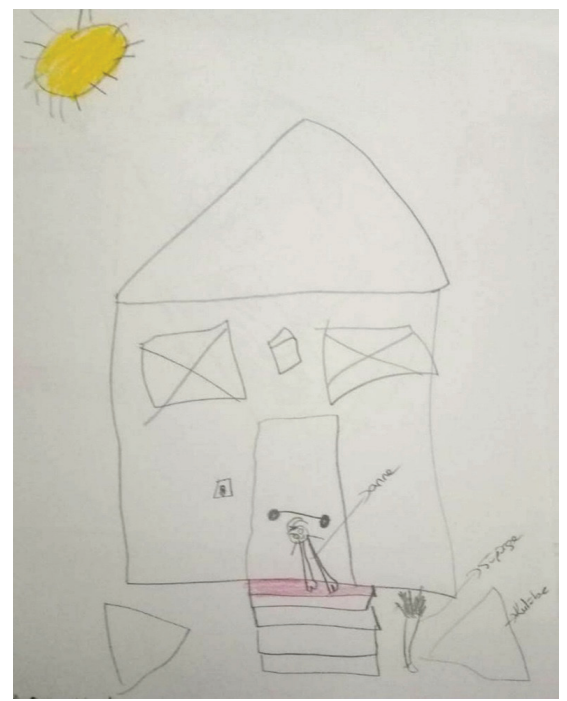

Şekil 8. Y isimli çocuğun resmi

“Oyun oynatır” kodunda yer alan bir başka erkek çocuk C: “Çok kar yağdlğında kartopu oynarız... Anneme kartopu atıyorum. Annem sadece dişarıya çok kar yağdı ̆̆ında çıkar.” şeklinde cevap vermiştir.

"Pazara gider" kodunda yer alan kız çocuk Z: "Pazara gidiyor. Poşetlerini yuvarlak çizeyim mi? Annem pazardan geliyor. Dur şuraya bir tane de bulut çizeyim. Bazen babam da gider pazara, herkes gider.” aynı kodda yer alan erkek çocuk MC: "Pazara gidiyor.” şeklinde kendilerini ifade etmişlerdir.

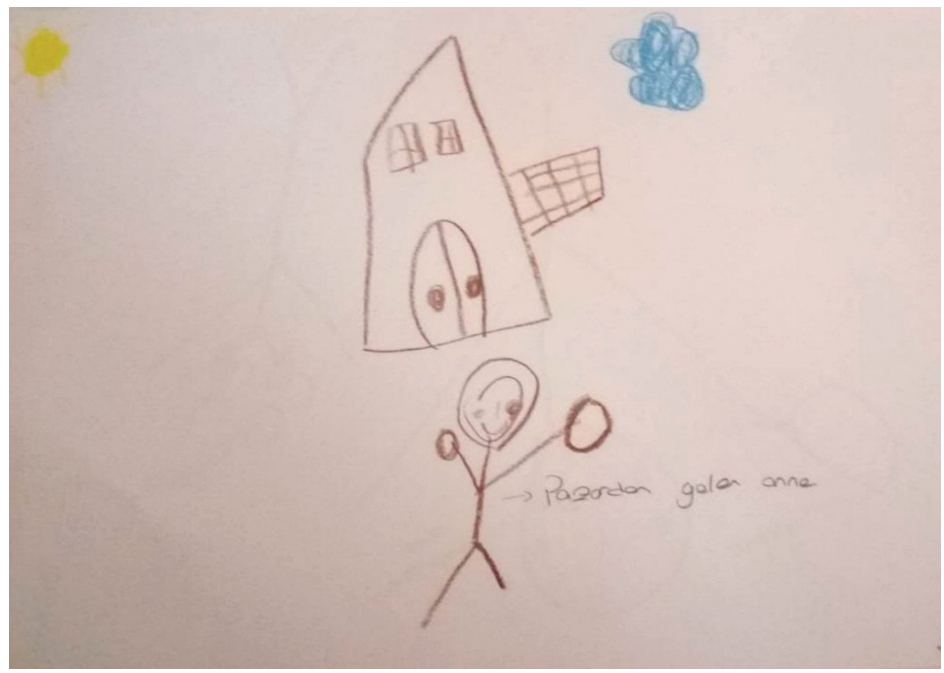

Şekil 9. Z isimli çocuğun resmi 
"Misafirliğe gider" kodu içerisinde yer alan erkek çocuk KZ: "Bazılarına geçmiş olsuna gider. Bazen misafirliğe gider."

“Arkadaşlarıyla konuşur” kodunda yer alan kız çocuk M: “Arkadaşlarıyla konuşur. Birbirleriyle konuşuyorlar. O kadarclk." şeklinde cevap vermişlerdir.

"Hiçbir şey yapmaz" kodu bağlamında yer alan kız çocuk Z: "Şey annem hiçbir yere gitmiyor. Sadece evde oturuyor." Aynı kodda yer alan erkek çocuk YÇ: “Annem dışarı çıktığında bir şey yapmaz.” şeklinde cevap vermiştir.

Tablo 2: “Annen Dışarıda Neler Yapar?” Sorusuna Yönelik Olarak Kız ve Erkek Çocuklarından Elde Edilen Kodlar

\begin{tabular}{|c|c|}
\hline Kod & Çocukların Örnek İfadeleri \\
\hline D1şarıyı süpürür. & Kız 5y/ Y: Dişarlyı süpürür, başka da bir şey yok. \\
\hline Merdiveni temizler. & Kız 5y/ Y: Merdiven temizliği yapıyo. \\
\hline Halı yıkamak. & Kız 5y/ B: Hall yıkar, burdan önlük takar o yüzden. \\
\hline Dişarıyı toplar. & Kız 5y/ Y: Dişarlyı toplamaya gidiyo. \\
\hline Mancarları sular. & Kız 5y/ B: Hall yıkar ve mancarlarl sular. \\
\hline Gezmeye götürür. & Erkek 5y/ Y: Beni gezdirir, bisikleti bu kadar yapabiliyorum. \\
\hline Parka götürür. & Erkek 5y/ YÇ: Beni parka götürüyor. \\
\hline Oyun oynatır. & Erkek 4y/ M: Beni oyun oynatırlar. \\
\hline Hiçbir şey yapmaz. & Kız 5y/ AD: Ama annem dişarda bi şey yapmaz ki. \\
\hline İşe gider. & Kız 4 BY: Isş falan işe falan gidiyor. Yani okula falan gidiyor. \\
\hline Pazara gider. & Kız 5y/ Z: Pazara gidiyor. \\
\hline Yemek alır. & Erkek 4y/ M: Mama alıyor evimize. \\
\hline Elbise alır. & Erkek 5y/ KZ: Annem klyafet alır bu mesela üst. \\
\hline Gezer. & K1z 5y/ ZB: Geziyor. Bizi de götürüyor. \\
\hline Sinemaya gider. & K1z 5y/ ZB: Sinemaya gider. \\
\hline $\begin{array}{l}\text { Arkadaşlarıyla vakit } \\
\text { geçirir. }\end{array}$ & Kız 5y/ BY: Bazen arkadaşları çağırınca dışarı gider. \\
\hline Arkadaşlarıyla konuşur. & Kız 5y/ EA: Dışarı çıkınca komşularla konuşur. \\
\hline Bahçeyi sular. & Erkek 5y/ MC: Annem bahçeyi sular. \\
\hline Okula götürür. & Erkek 5y/ B: Okula gidiyoruz. \\
\hline Kardan adam yapar. & Erkek 5y/ AB: Annemle ikimiz dışarıda kardan adam yaparız. \\
\hline Aşağıda temizlik yapar. & Erkek 4y/ M: Aşağıda biraz temizlik yapar. \\
\hline Doktora gider. & Erkek 5y/ Y: Doktora gider. \\
\hline Sohbet eder. & Erkek 4y/ Ç: Kendisiyle dışarıda sohbet ediyor. \\
\hline Oturur. & Erkek 4y/ Ç: Oturuyor. \\
\hline Misafirliğe gider. & Erkek 5y/ KZ: Bazılarına geçmiş olsuna gider, bazen misafirliğe gider. \\
\hline Süt alır. & Erkek 5y/ B: Süt alıyoruz. \\
\hline
\end{tabular}

\section{“Annen Evde Neler Yapar?’ Bölümüne Yönelik Bulgular (Kategoriler)}

Araştırmacı kodları tekrarlı okumaları ile bazı kodlar arasındaki benzerlikler olduğunu fark etmiş, bunları çeşitli gruplar altında toplama ihtiyacı doğrultusunda çeşitli kategorilere ulaşmıştır. “Annen evde neler yapar?” sorusuna yöne- 
lik olarak elde edilen kategoriler şu şekildedir; "yemek yapmak", "evi toparlamak", "iç temizlik", "tv izlemek". Kız ve erkek çocukların kategorilerinde ortak olmayanlar ise, kız çocuklarında yukarıda elde edilen kategorilere ek olarak; "el işi yapmak", "kediye yemek hazırlamak" kategorileridir. Erkek çocukların kızlarla ortak olmayan diğer kategorileri; "ütü yapmak", "çocuklarla ilgilenmek" şeklindedir. Hangi kodların aynı grup altında yer alarak kategorileri oluşturduklarına ilişkin tablo aşağıda yer almaktadır.

Tablo 3: “Annen Evde Neler Yapar?” Sorusuna Yönelik Olarak Kız ve Erkek Çocuklardan Elde Edilen Kategoriler

\begin{tabular}{ll}
\hline Kategori & İlişkin Kod \\
\hline Yemek yapmak. & Yemek yapar. \\
\hline Evi toparlamak. & Evi toplar. \\
& Yatağı toplar. \\
& Oyuncakları toplar. \\
\hline İç temizlik. & Evi süpürür. \\
& Evi siler. \\
& Temizlik yapar. \\
& Bulaşı yıkar. \\
& Çamaşır yıkar. \\
\hline Tv izlemek. & Televizyon izler. \\
\hline El işi yapmak. & El işi yapar. \\
\hline Kediye yemek hazırlamak. & Kediye yemek hazırlar. \\
\hline Çocuklarla ilgilenmek. & Boyama yapar. \\
\hline
\end{tabular}

Tabloda görüldüğü üzere annelerin evde temizlik yapmaya, yemek yapmaya, evi düzenlemeye ve hobilere yönelik işler yapmaya dair davranışları olduğu görülmektedir.

\section{‘'Annen Dişarıda Neler Yapar?’' Bölümüne Yönelik Bulgular (Kategoriler)}

Araştırmacı bir önceki bölümde yaptı̆̆ı işlemlerle benzer şekilde tekrar tekrar okuduğu kodlar doğrultusunda, kodlarla benzeşik olarak daha gruplandırılmış kategorilere ulaşmıştır. "Annen dışarıda neler yapar?” sorusuna yönelik olarak k1z ve erkek çocuklarından elde edilen kategoriler şu şekildedir; "dış temizlik", "bitki sulamak", “çocuklarla ilgilenmek”, "bir şey yapmamak”, "pazara gitmek", “yemek almak", “elbise almak”, “eğlence”, “arkadaşlarla vakit geçirmek". K1z ve erkek çocukların kategorilerinde ortak olmayanlar ise, kız çocuklarında yukarıda elde edilen kategorilere ek olarak; "dışarıyı toparlamak”, "işe gitmek" kategorileridir. Erkek çocukların kızlarla ortak olmayan diğer kategorileri; "doktora gitmek", "süt almak” şeklindedir. 


\begin{tabular}{|c|c|}
\hline Kategori & İliş̧kin Kod \\
\hline Diş temizlik. & $\begin{array}{l}\text { Aşağııda temizlik yapar. } \\
\text { D1şarıyı süpürür. } \\
\text { Merdiveni temizler. } \\
\text { Halı yıkar. }\end{array}$ \\
\hline Dışarıyı toparlamak. & Dişarıyı toparlar. \\
\hline Bitki sulamak. & $\begin{array}{l}\text { Mancarları sular. } \\
\text { Bahçeyi sular. }\end{array}$ \\
\hline Çocuklarla ilgilenmek. & $\begin{array}{l}\text { Gezmeye götürür. } \\
\text { Parka götürür. } \\
\text { Oyun oynatır. } \\
\text { Okula götürür. } \\
\text { Kardan adam yapar. }\end{array}$ \\
\hline Bir şey yapmamak. & Hiçbir şey yapmaz. \\
\hline İşe gitmek. & İşe gider. \\
\hline Pazara gitmek. & Pazara gider. \\
\hline Yemek almak. & Yemek alır. \\
\hline Elbise almak. & Elbise alır. \\
\hline Eğlence. & $\begin{array}{l}\text { Gezer. } \\
\text { Sinemaya gider. }\end{array}$ \\
\hline Arkadaşlarla vakit geçirmek. & $\begin{array}{l}\text { Arkadaşlarıyla vakit geçirir. } \\
\text { Arkadaşlarıyla konuşur. } \\
\text { Sohbet eder. } \\
\text { Oturur. } \\
\text { Misafirliğe gider. }\end{array}$ \\
\hline Doktora gitmek. & Doktora gider. \\
\hline Süt almak. & Süt alır. \\
\hline
\end{tabular}

Çocukların “Annen dişarıda neler yapar?” sorusuna yönelik olarak gözlemlerine ve buna bağlı ifadelerine göre annelerinin evde yaptıkları davranışlarla kıyaslandığında dışarıdaki davranışlarının biraz daha farklılık ve çeşitlilik gösterdiği hissedilmektedir. Fakat yine de annelerin dışarıda yaptıkları işlerin de yine ağırlıklı olarak eve yönelik işler, eve yönelik alışveriş, temizlik, çocuklara yönelik aktiviteler olduğu dikkati çekmektedir.

\section{“Annen Evde Neler Yapar?” Bölümüne Yönelik Bulgular (Temalar)}

Çok fazla sayıda kategori ve bunlara bağlı kod elde edilmiş olması araştırmanın anlaşılırlı̆̆ 1 ve özetlenmesi konusunda sıkıntı yaratacağı kaygısı ve nitel araştırmaların temel doğası gereğince bu bölüm ve bir sonraki bölümde temalara ulaşmaya dair yapılan işlemler ve ulaşılan temalardan bahsedilmiştir.

Araştırmacı tekrar tekrar okuduğu kod ve kategoriler doğrultusunda kategorileri azaltıcı ve toparlayıcı temalara ulaşmıştır. "Annen evde neler yapar?" 
sorusuna yönelik olarak kız ve erkek çocukların görüşlerinden elde edilen kategorilerden araştırmacının ulaştı̆̆ ilk temalar şu şekildedir; "yemek yapmak", "düzenlemek", "temizlik", "evde aktivite yapmak". Kız ve erkek çocukların temalarında ortak olmayanlar ise, kız çocuklarında yukarıda elde edilenlere ek olarak; "canlı bakımı" temasıdır. Erkek çocukların kızlarla ortak olmayan temaları; "çocuklarla ilgilenmek" şeklindedir.

Tablo 5: “Annen Evde Neler Yapar?” Sorusuna Yönelik Olarak İlk Elde Edilen Temalar

\begin{tabular}{ll}
\hline Tema & Kategori \\
\hline Yemek yapmak. & Yemek yapmak. \\
\hline Düzenlemek. & Evi toparlamak. \\
\hline Temizlik. & İç temizlik. \\
\hline Canlı bakımı. & Kediye yemek hazırlamak. \\
\hline Evde aktivite yapmak. & El işi yapmak. \\
\hline Çocuklarla ilgilenmek. & Tv izlemek. \\
\hline
\end{tabular}

Araştırmacılar ilk elde edilen temaları incelediklerinde annelerin evin düzenlenmesi ve temizlenmesine yönelik yaptıkları işlerin yoğunlukta olduğunu, temaların üçünün buna yönelik olması sonucu fark etmişlerdir (Yemek yapmak, düzenlemek, temizlik). Nitel verileri desteklemek üzere kayıt edilen sayısal verilerde de bu temalara ait davranışların çocukların çoğunluğu tarafından ifade edildiği görülmüştür. Çocukların ifadelerinin çoğunda temizlik ve düzen temasını oluşturacak davranışlar geçmiştir; "temizlik yapar" on iki ifadede, "bulaşık yıkar" sekiz ifadede, "evi toplar" iki ifadede, "yatağı toplar” üç ifadede, "evi süpürür" dört, "çamaşır yıkar" iki ifadede gibi kız ve erkek çocukların ifadelerinde geçmiştir. Çocukların temizlik ve düzenlemek temalarına ait yoğun ifadelerini takip eden ise "yemek yapmak" temasına ait görüşleri olmuştur. Toplamda on üç ifadede kız ve erkek çocukları “yemek yapar”a yönelik görüş belirtmişlerdir.

Bunlarla beraber "canlı bakımı", "evde aktivite yapmak", "çocuklarla ilgilenmek" temalarına yönelik ifadelerin niceliksel olarak daha az geçtiği fark edilmiştir. Örneğin "kediye yemek hazırlar" bir ifadede, "el işi yapar" bir ifadede, "televizyon izler" ise iki ifadede geçmektedir. Özellikle evde aktivite yapmaya dair az ifade olduğu, annelerin evde genellikle kendilerine yönelik değil, eve ve diğer kişi/canlılara yönelik davranışları olduğunu hissettirmektedir. Yine buna paralel olarak çocuklarla ilgilenmek teması altında yer alan örnek ifadeler; "boyama yapar" ve "çizgi film izler" toplamda iki ifadede geçmekte ve annelerin evde temizlik ve yemek dışında yaptıkları aktivitelerin bile daha çok başkalarını hoşnut etmeye yönelik şeyler olduğunu bize düşündürmektedir. 
$\mathrm{Bu}$ sebeple temalar yeniden incelenerek bazı temaların bir grup, diğer temaların ise farklı iki grup altında toplanmasının daha uygun olacağı düşünülmüştür. Buna göre annelerin ev içerisinde yaptıklarına yönelik "yemek yapmak", "düzenlemek", "temizlik" temaları "ev düzeni", "canlı bakımı" ve "çocuklarla ilgilenmek" temaları "diğerlerine ilgi" ve "evde aktivite yapmak" ise "kendine ilgi" olarak yeniden düzenlenmiştir.

\begin{tabular}{ll}
\hline Tablo 6: “Annen Evde Neler Yapar?” Sorusuna Yönelik Olarak Son Elde Edilen Temalar \\
\hline Son Tema & İlk Tema \\
\hline \multirow{3}{*}{ Ev düzeni. } & $\begin{array}{l}\text { Yemek yapmak. } \\
\text { Düzenlemek. } \\
\text { Temizlik. }\end{array}$ \\
\hline Diğerlerine ilgi. & $\begin{array}{l}\text { Canlı bakımı. } \\
\text { Çocuklarla ilgilenmek. }\end{array}$ \\
\hline Kendine ilgi. & Evde aktivite yapmak. \\
\hline
\end{tabular}

\section{“Annen Dışarıda Neler Yapar?” Bölümüne Yönelik Bulgular (Temalar)}

Bir önceki bölümde olduğu gibi bu bölümde de temalara ulaşılmaya çalışı1mıştır. "Annen dışarıda neler yapar?” sorusuna yönelik olarak elde edilen ilk temalar şu şekildedir; "canlı bakımı", "çocuklarla ilgilenmek", "bir şey yapmamak", "temizlik", "sosyal aktivite", "alışveriş yapmak". Kız ve erkek çocukların temalarında ortak olmayanlar ise, kız çocuklarında yukarıda elde edilenlere ek olarak; "düzenlemek", "işe gitmek” temalarıdır. Erkek çocukların kızlarla ortak olmayan diğer temaları; "doktora gitmek" şeklindedir.

\begin{tabular}{ll}
\hline Tablo 7: “Annen Dişarıda Neler Yapar?” Sorusuna Yönelik İlk Elde Edilen Temalar \\
\hline Tema & İlişkin Kategori \\
\hline Canlı bakımı. & Bitki sulamak. \\
\hline Çocuklarla ilgilenmek. & Çocuklarla ilgilenmek. \\
\hline Bir şey yapmamak. & Bir şey yapmamak. \\
\hline Temizlik. & Diş temizlik. \\
\hline Doktora gitmek. & Doktora gitmek. \\
\hline Sosyal aktivite. & Arkadaşlarla vakit geçirmek. \\
\hline & Eğlence. \\
\hline \multirow{2}{*}{ Alışveriş yapmak. } & Pazara gitmek. \\
& Süt almak. \\
\hline Düzenlemek. & Yemek almak. \\
\hline İşe gitmek. & Elbise almak. \\
\hline
\end{tabular}

Elde edilen ilk temalar incelendiğinde çok fazla olduğu hissedilmiştir. Nitel araştırmaların doğası gereği azaltılması ve daha bütünsel hale getirilmesi amacıyla tekrar gözden geçirilmiştir. Bu gözden geçirme sonucu araştırmacılar 
elde edilen bazı temaların birbirine benzeşiklik gösterdiğini ve aynı çatı altında toplanabileceğini düşünmüşlerdir. Örneğin bir önceki bölümdekine benzer şekilde "düzenlemek" ve "temizlik" temaları bu sefer dışarıyı kapsamakla birlikte birbirlerine benzer özellikler göstermektedirler. Elde edilen ilk temalar incelendiğinde annenin dişarıda sorumluluklarını yerine getirmeye dair eylemlerinin olduğu görülmüştür. Örneğin "işe gitmek", "canlı bakımı" ve "doktora gitmek" gibi. Bir önceki bölümde de ilk temalarda yer alan "canlı bakımı" burada "diğerlerine ilgi” olarak hissedilmemiştir çünkü bir önceki bölümdeki bir kedi iken, çocuklar burada mancarlar ve bitkilerden söz etmiştir. Bu da daha çok ilgi değil sorumluluk olarak düşünülebilir. İlk elde edilen temalardaki "alışveriş yapmak" teması da aslında sorumluluklara dair daha çok görüş içermektedir. Çünkü burada annenin çoğu aldıkları (pazara gitmek, süt almak, yemek almak) sadece kendine değil yine evdeki herkese lazım olacak şeyleri ifade etmektedir. Belki bu temanın bölünmesi yararlı görülebilir. "Sosyal aktivite" teması annenin kendine yönelik yaptığı eylemleri ifade ettiği için elbise almak kategorisini de buraya ekleyebiliriz. Bu yeniden gözden geçirme sonucu temalar elenmiş ve yenileri oluşturulmuştur. Buna göre "temizlik" ve "düzenlemek" temaları "dış düzen” temasını, "işe gitmek", "canlı bakımı", "doktora gitmek”, "alışveriş yapmak" temaları "sorumluluk" temasını, "sosyal aktivite", "olumlu kendine ilgi” temasını, "bir şey yapmamak", "olumsuz kendine ilgi” temasını, "çocuklarla ilgilenmek" ise, "çocuklara ilgi" temasını oluşturmuştur. Bu şekilde yeniden düzenlenen son temalar aşağıda özetlenmiştir.

\begin{tabular}{ll}
\hline Tablo 8: “Annen Dışarıda Neler Yapar?” Sorusuna Yönelik Olarak Son Elde Edilen Temalar \\
\hline Son Tema & İlk Tema \\
\hline Dış düzen. & Temizlik. \\
& Düzenlemek. \\
\hline Sorumluluk. & İşe gitmek. \\
& Canlı bakııı. \\
& Doktora gitmek. \\
& Alışveriş yapmak. \\
\hline Olumlu kendine ilgi. & Sosyal aktivite. \\
\hline Olumsuz kendine ilgi. & Bir şey yapmamak. \\
\hline Çocuklara ilgi. & Çocuklarla ilgilenmek. \\
\hline
\end{tabular}

Çocuklardan elde edilen nitel veriler, nicel açıdan incelendiğinde ev dışındaki etkinliğe dair görüş frekanslarının, ev içerisinde annenin yaptıklarına göre farklılık ifade ettiği görülmüştür. Örneğin annelerin ev içerisinde kendilerine yönelik ilgilerinin ve yaptıkları eylemlerin ifadesi az olmasına rağmen bu bölümde bu durum değişmiştir. Çocukların “Annen dışarıda neler yapar?” sorusu- 
na yönelik ifadelerinden elde edilen görüşlerde "olumlu kendine ilgi”" temasının ifadeleri ön plana çıkmaktadır. Dışarıda sosyal aktiviteye yönelik çocukların ifadelerinde on dört öğe geçmiştir. Bunlar "gezer", "sinemaya gider", "arkadaşlarıyla vakit geçirir", "arkadaşlarıyla konuşur" gibi ifadelerdir. Bunların içerisinde ise en çok "gezer" ifadesi geçmiştir. Bu araştırmada yer alan annelerin kendilerine yönelik olumlu-hoşnutluk verici bir eylem gerçekleştireceklerse bunu evde değil dışarıda yapmayı tercih ettikleri düşünülebilir. Evde kendine yönelik ilgi düşük frekansta iken ev dışında kendine yönelik ilgi yüksektir.

Annelerin dışarıda kendilerine yönelik eylemlerinden sonra en çok ifadesi geçen temalar; "sorumluluk" ve "çocuklara ilgi" temaları olmuştur. Sorumluluk temasındaki on bir ifade (işe gitmek, bitki sulamak, pazara gitmek gibi) ve çocuklara ilgi temasındaki on ifade (parka götürmek, oyun oynatmak, kardan adam yapmak gibi), yoğunlukları ile olumlu kendine ilgi temasını takip etmektedirler. Annelerin dışarıda da, ev içindekine benzer şekilde aktif olarak kendileri dışındaki kişilerle ve sorumlulukları ile ilgili davranışlar gerçekleştirdikleri söylenebilir.

Dış düzene yönelik davranışları da ev içerisindeki kadar yoğun olmasa da devam etmektedir. Beş ifadede "aşağıda temizlik yapar", "dışarıyı süpürür", "merdiveni temizler", "halı yıkar" gibi ifadeler geçmektedir.

Araştırmacıların en çok dikkatini çeken tema "olumsuz kendine ilgi" teması olmuştur. Bu ifadelerde "hiçbir şey yapmaz" ifadesi geçmektedir. Bu durum bazı çocukların annelerinin hiç dışarı çıkmadıkları/az çıktıkları veya çıktıklarında çocukların ifade etmelerine değer-ilgilerini çeken şeyler yapmadıkları veya çocukların ne yaptıklarını görmedikleri gibi çeşitli şekillerde yorumlanabilir. Sonuçta bu durumun anneler adına olumsuz bir hissiyat verdiği ön görülebilir. Bu annelerin isteyerek veya istemeyerek asosyal oldukları düşünülebilir. Erkek çocuk C'nin ifadesi dikkat çekmektedir; "Annem sadece dı̧̧arıya çok kar yağdı̆̆ında çıkar” ve yine kız çocuk Z'nin "Şey annem hiçbir yere gitmiyor. Sadece evde oturuyor." şeklinde dikkati çeken ifadesi olmuştur. Annen dişarıda neler yapar bölümüne yönelik olarak bir başka ilgi çekici nokta, işe gitmek ifadesini kullanan bütün çocukların kız çocuğu olduğudur. Erkek çocuklarında “işe gitmek” ifadesinin hiç geçmediği görülmüştür.

Çocukların ifadelerinin (kodlamayı netleştirme işlemi öncesi sözel ifadeler) niceliksel olarak gösterimi ise Tablo 9 ve 10 'da yer almaktadır. 
Tablo 9: “Annen Evde Neler Yapar?” Sorusuna İlişkin Sayısal Tablo

\begin{tabular}{lll}
\hline Kod & Kiz & Erkek \\
\hline Yemek yapar. & 7 & 6 \\
\hline Temizlik yapar. & 6 & 6 \\
\hline Evi toplar. & 1 & 1 \\
\hline Yatağı toplar. & 1 & 3 \\
\hline Evi süpürür. & 1 & 4 \\
\hline Bulaşık yıkar. & 4 & - \\
\hline Kediye yemek hazırlar. & 1 & - \\
\hline El işi yapar. & 1 & 1 \\
\hline Televizyon izler. & 1 & 1 \\
\hline Evi siler. & - & 1 \\
\hline Çamaşır yıkar. & 1 & 1 \\
\hline Oyuncakları toplar. & - & 1 \\
\hline Boyama yapar. & - & 1 \\
\hline Çizgi film izler. & - & 1 \\
\hline
\end{tabular}

Tablo 10: “Annen Dışarıda Neler Yapar?” Sorusuna İlişkin Sayısal Tablo

\begin{tabular}{|c|c|c|}
\hline Kod & $\mathrm{K} 1 \mathrm{Z}$ & Erkek \\
\hline D1şarıyı süpürür. & 1 & - \\
\hline Merdiveni temizler. & 1 & - \\
\hline Halı yıkamak. & 1 & - \\
\hline Dişarıyı toplar. & 1 & - \\
\hline Mancarları sular. & 1 & - \\
\hline Gezmeye götürür. & 1 & 1 \\
\hline Parka götürür. & 1 & 1 \\
\hline Oyun oynatır. & 2 & 2 \\
\hline Hiçbir şey yapmaz. & 3 & 1 \\
\hline İşe gider. & 3 & - \\
\hline Pazara gider. & 1 & 1 \\
\hline Yemek alır. & 1 & 1 \\
\hline Elbise alır. & 1 & 1 \\
\hline Gezer. & 3 & 1 \\
\hline Sinemaya gider. & 1 & - \\
\hline Arkadaşlarıyla vakit geçirir. & 3 & - \\
\hline Arkadaşlarıyla konuşur. & 1 & - \\
\hline Bahçeyi sular. & - & 1 \\
\hline Okula götürür. & - & 1 \\
\hline Kardan adam yapar. & - & 1 \\
\hline Aşağıda temizlik yapar. & - & 1 \\
\hline Doktora gider. & - & 1 \\
\hline Sohbet eder. & - & 1 \\
\hline Oturur. & - & 1 \\
\hline Misafirliğe gider. & - & 1 \\
\hline Süt alır. & - & 1 \\
\hline
\end{tabular}




\section{Tartışma ve Öneriler}

Okul öncesi dönemdeki 4-6 yaş arası çocukların annelerinin ev içi ve ev dışı rollerine yönelik görüşlerinin, toplumsal cinsiyet açısından incelenmesinin amaçlandığı bu araştırmanın tartışma ve önerilerine bu bölümde yer verilmiştir.

Süreçte çocuklara "Annen evde neler yapar?" ve "Annen dışarıda neler yapar?" soruları yöneltilmiş ve bu iki durumla ilgili resim çizmeleri ve çizdikleri resimleri anlatmaları istenmiştir. Çocuklardan alınan görüşler incelenip bu doğrultuda kod, kategori ve temalara ulaş1lmıştır.

Araştırma sonucunda çocukların annelerinin evde ve dışarıda neler yaptığına yönelik görüşlerinden temalara ulaşılmıştır. Annelerinin evde neler yaptığına yönelik; yemek yapmak, düzenlemek, temizlik gibi alt temaları içeren "ev düzeni” temasına, canlı bakımı, çocuklarla ilgilenmek gibi alt temaları içeren "diğerlerine ilgi" temasına ve evde aktivite yapmak alt temasını içeren "kendine ilgi" temasına ulaşılmıştır.

Annelerinin dışarıda neler yaptığına yönelik olarak ise; arkadaşlarla sohbet etmek, sinemaya gitmek gibi sosyal aktivite alt temasını içeren "olumlu kendine ilgi”, işe gitmek, canlı bakımı, alışveriş yapmak, doktora gitmek gibi alt temaları içeren "sorumluluk", çocuklarla ilgilenmek alt temasını içeren "çocuklara ilgi”, temizlik ve düzenleme alt temalarını içeren "dış düzen" ve bir şey yapmamak alt temasını içeren "olumsuz kendine ilgi" temalarına ulaşılmıştır.

Elde edilen temalarda dikkat çeken bir nokta olarak, "ev düzeni” temasının içerisinde yer alan yemek yapma ve temizlik yapmaya dair görüşlerin, çocukların sıklıkla ifade ettikleri bir anne davranışı olarak yer aldığıdır. Bu durum çocukların anne toplumsal cinsiyet kimliğini, yemek yapma ve temizlik yapma şeklinde benimsediklerini veya evde yaşanan gerçeği olduğu gibi yansıttıklarını düşündürmektedir. Evdeki gerçekliği yansıttıkları düşünüldüğünde kadının ev içinde yemek yapma ve temizlik yapma konusunda aktif rol üstlendiği, erkeğin ise bu işlerde geri planda kaldığı düşünülebilir.

Benzer şekilde Akar ve Aksoy'un (2018) yaptığı çalışmada, erken ve orta çocukluk dönemi çocuklarının annelerini mutfakta yemek ve temizlik yapan olarak betimledikleri görülmektedir. Başka bir araştırmada 5 yaş çocuklarının cinsiyet kalıp yargı düzeyleri ve evdeki cinsiyet rollerine ilişkin görüşlerinin incelenmesi sonucu elde edilen verilere göre, yemek pişirme, masa hazırlama ve toplama gibi benzer işlerde annelerinin daha aktif rol aldıklarını belirttiklerini 
saptamışlardır (Ata Doğan, Atış Akyol ve Güney Karaman, 2018). Aytekin ve diğerlerinin (2016), 4-6 yaş arası çocukların anne babalarına yönelik algıları$\mathrm{n} ı$ inceledikleri bir çalışmada, çocukların genel anlamda geleneksel toplumsal cinsiyet rolleri algısına sahip oldukları ve annelerini evde ev işi ve yemek yapan olarak betimledikleri görülmektedir. Yine araştırmaya paralel olarak Bağçeli Kahraman ve Arabacıoğlu (2018), yaptıkları çalışmada "Anne ne yapar?" sorusuna yönelik olarak çocuklardan; yemek yapar, temizlik yapar, çocuklara bakar, ev işlerini yapar, çocuklarını sever cevaplarına ulaşıldığı görülmektedir. Destekler nitelikte olarak Şıvgın (2015)'ın, cinsiyet rolleri eğitim etkinliklerinin, anasınıfına devam eden 60-72 aylık çocuklarına toplumsal cinsiyet kalıp yargılarına etkisini incelediği çalışmasında, deney ve kontrol grubundaki çocukların \%100’ü yemek, ütü, temizlik ve misafirlerle ilgilenmek maddelerini kadın görevi olarak ifade etmiştir.

Benzer şekilde Bee ve Boyd (2009) çocukların iki yaşından itibaren belirli görevleri, eşyaları erkek ve kadınlarla ilişkilendirdiklerini buna örnek olarak kadınları elektrikli süpürge ve yemekle; erkekleri ise otomobil, tamir aletleriyle ilişkilendirdiklerini ifade etmişlerdir. Bu araştırmadaki kız ve erkek çocukların da annelerinin ev içerisinde düzenleme ve temizlemeye dair eylemlerine yönelik ifadeleri olmuştur.

Yaptığımız araştırmada yukarıda belirtilenlere ek olarak çocukların annelerini evde temizlik yapar olarak betimledikleri gibi, dışarıda da temizlik yapar olarak betimledikleri fark edilmiş ve bu yönde bir tema elde edilmiştir (Dış düzen). Çocukların annelerinin ev içerisinde düzene yönelik yaptıkları davranışlara benzer şekilde dışarıda da düzen ile ilgili davranışlar sergilediklerini belirtmeleri, çocukların annelerini dışarıda da evdekine benzer şekilde algıladıklarının bir ifadesi olabilir. Veya yine çocukların bize gerçeği yansıttıklarını ve kadınların dışarıda da temizlik ile ilgili işleri yapmaktan "kurtulamadıklarının" bir göstergesi olabilir. Ayrıca bu durum çocukların ev içerisindeki geleneksel toplumsal cinsiyet kimliği algılarını, ev dışında da sürdürdüğünün bir göstergesi olabilmekle beraber anneyi dışarıda da daha çok düzen sağlayan olarak algılamalarından kaynaklanabilir. Bu, çocuklar açısından olumlu görülen bir durum olabilir.

Kalıp yargılara yönelik bir yorumunda İmamoğlu (2012); "toplumsal cinsiyet kalıp yargılarının" geleneksel aile yapısında, kadınların sorumluluğunun çocuk bakımı ve evin düzenini sağlamakla yükümlü kılınarak, kadınları daha çok düzenleyici rolüne atfettiğinden bahsetmiştir. Bu durum, bu araştırmada yer alan 
çocukların da hem algılarında hem de ifadelerinde kadınların sorumluluğunun evin düzenleyicisi olarak görüldüğünü, buna ek olarak kadınların ev içerisinde ve dışında zaten bu rolleri fazlasıyla üstlendiklerini, erkeklerin ise bu sorumlulukta geride kaldıklarını düşündürebilir. Benzer bir araştırmada Aytekin ve diğerleri (2016), çocukların çoğunluğunun annelerini ev içinde ev işi yapan ve mutfak işi yapan, bunları yapmaktan hoşlanan kişi olarak tanımladıkları görülmüştür. Kadınların kendilerine toplum tarafından biçilen cinsiyet kalıp yargılarını benimsedikleri düşünülebilir.

Ebeveynler ev içinde ve dışında geleneksel roller sergiledikçe ve bu rollerin çocuklar için daha uygun olduğunu düşündükçe ve onlara aşıladıkça, geleneksel rollerin model olarak çocuklar tarafından alınmasını ve oluşmasını desteklemiş olurlar (Baran, 1995). Ex ve Janssens (2000), kızların toplumsal cinsiyet rolü davranışlarında annelerin etkisini inceledikleri araştırmalarında, genel anlamda annelerin çocuk yetiştirme stili ve toplumsal cinsiyet rolü algılarının, kızlarının geliştirmekte olduğu toplumsal cinsiyet rolü davranışlarını etkilediği sonucuna ulaşmışlardır. Fulcher ve diğerlerinin (2007) yaptıkları bir çalışmada ise ev içinde eşler arasında paylaşılan rollerin çocuklarda toplumsal cinsiyet tutumlarını etkiledikleri sonucuna ulaşılmıştır (akt. Yağan Güder ve Güler Yıldız, 2016).

Özetle anneler ve babalar çocuklarına, toplumsal cinsiyet kalıp yargı türünden geleneksel roller sergilediğinde çocuklarda bu geleneksel rolleri içselleştirmektedirler. Bu araştırmada bundan dolayı çocukların hem evde hem de dışarıda annelerini geleneksel bir bakış açısıyla tasvir ettikleri ki zaten annelerinin de buna uygun davrandıkları yani kendilerine "biçilen" davranışları yaptıklarını düşünebiliriz.

Bununla beraber bu durumun çocukların ailesindeki durumu tam gerçeklikle yansıtmadığını, çocukların algılarını yansıttığını düşündüğümüz takdirde, çocukların algılarına kaynaklık eden dış etkenlerin varlığını düşünmemiz gerekebilir. Örneğin; Gürşimşek ve Günay Doğan'ın (2005) çocuk kitaplarında cinsiyet rollerinin işlenişinde kullanılan dilsel ve dil dışı göstergelerini inceledikleri araştırmalarında genel anlamda dişil nesnelerin daha keskin biçimde cinsiyet rollerini belirttiği ve annenin daha çok düzen sağlayan bir yapıda oldukları belirtilmiştir. Aynı şekilde Dilek'in (2014) araştırmasında da çocuk kitaplarında yer alan kadın kahramanların genellikle "ev hanımı” şeklinde tasvir edildiği bulunmuştur. Çocuklara ev içerisinde geleneksel roller sunulmasa bile, özellikle bu dönemde karşılaştıkları çocuk kitaplarının da algılarını şekillendirmede etkisinin olabileceği düşünülebilir. 
"Annen dişarıda neler yapar?" sorusuna yönelik olarak "işe gitmek" kategorisinde sadece kız çocuklarının ifadelerinin yer aldığı, erkek çocuklarının ise annelerini işe gider nitelikte betimlemedikleri görülmüştür. Bu durum bu örneklemdeki kızlar ve erkekler arasında tesadüfi olabileceği gibi, erkek çocuklarının anne rolünü daha geleneksel olarak benimsediklerinin bir ifadesi de olabilir. Okul öncesi dönemdeki çocuklarla yapılan bir araştırmada annelerinin mesleklerinin gelenekselliğinin, çocukların mesleki ilgilerinin gelenekselliği üzerinde etkisi olup olmadığ incelenmiş̧ir. Araştırmanın sonucunda ise anne mesleklerinin gelenekselliğinin (yani annenin terzi olması gibi), çocukların mesleki ilgilerinin gelenekselliği ile bağlantılı olduğu görülmüştür (Barak ve diğerleri, 1991; akt. Baran, 1995). Yani annelerin çalışma durumları kadar, mesleklerinin geleneksel olup olmaması da çocukların algılarını etkileyebilmektedir. $\mathrm{Bu}$ sebeple erkek çocuklarının anneleri daha geleneksel mesleklerde çalışıyor ve bunun sonucu olarak erkek çocukları annelerini daha geleneksel, ev kadını şeklinde algilıyor olabilirler.

4-6 yaş arası çocukların annen dışarıda neler yapar sorusuna yönelik olarak verdikleri cevaplar doğrultusunda çıkan "hiçbir şey yapmamak" kategorisi ise dikkati çekicidir. Bu durum çocukların anne toplumsal cinsiyet rollerine yönelik olarak, annelerini sadece ev içerisinde aktif ve "ev kadını" olarak algıladıklarının ifadesi olabilir. Ayrıca annelerinin hayatlarının büyük çoğunluğunun evde geçtiği, sosyal ortama katılma gibi durumlarının olmadığının da bir göstergesi olabilir.

Araştırmadaki çocukların önemli bir bölümünün ev içerisindeki anne rollerine yönelik olarak toplumsal cinsiyet kalıp yargılarını destekleyen görüşlere sahip oldukları ve annelerinin de bu cinsiyet kalıp yargılarına uygun şekilde evde ve daha az yoğunlukla olmak üzere dışarıda davranışlar sergiledikleri düşünülebilir. Çocukların annelerinin ev içi davranışlarına yönelik görüşlerinde yoğunluğu yemek ve temizlik işlerine yönelik görüşleri oluşturmaktadır. Dışarıya yönelik görüşlerinde ise bu durum nispeten hafiflemekte ve başka etkinlikleri de annelerinin yaptığını belirtmektedirler.

Çocuk ebeveynleriyle sosyal ilişkiler kurarken ebeveynleri rol model olarak görmekte ve bunlara yönelik zihninde kadın ve erkek rolleri oluşmaktadır (Bağçeli Kahraman ve Arabacioğlu, 2018). Çocuklar bu süreçte rollere ilişkin bilgi edindikleri gibi aynı zamanda rollere yönelik kalıp yargıları edinmekte ve ortaya toplumsal cinsiyete dayalı eşitsizlikler çıkmaktadır (Yağan Güder ve Güler Yıldız, 2016). Yani ebeveynlerin rol algıları ve rol paylaşımları çocukları 
toplumsal cinsiyet rol algıları bakımından dolaylı ya da doğrudan etkileyebilir. Fulcher ve diğerlerinin (2007) yaptıkları bir araştırma ebeveynler arasındaki evdeki geleneksel iş bölümlerinin, erkek çocukları daha eril iş seçimine yönlendirirken kızları ise daha dişil iş seçimlerine yönlendirdiği göstermiştir (akt. Yağan Güder ve Güler Yıldız, 2016). Okulöncesi dönemde çocukların model alarak öğrenmelerini göz önünde bulundurursak, toplumsal cinsiyet eşitsizliğinin üretilmemesi için anne ve babaların, toplumsal cinsiyet sorumlulukları bağlamında mümkün olduğunca eşitlikçi bir yapıda rol model olmaları, ev içi ve dışı aile sorumluluklarının paylaşımında kadın ve erkek arasında dengeli bir dağılım gözetmeye çalışmaları, söylevlerinde karşıt cinsiyeti aşağılayan tarzda ifadeler kullanmamaları, toplumsal cinsiyet eşitliğine duyarlı bireyler yetiştirmeleri ve bu konuda ailelere ve çocuklara eğitim çalışmalarının düzenlenmesi toplumsal yaşama dair öneriler olarak sunulmaktadır.

İleride yapılacak araştırmalara yönelik olarak, farklı bölgelerdeki çocukların görüşlerinin alınmasına yönelik araştırmalar yapılabilir. Bu yapılacak araştırmalarda aile içi gözlemlere yönelik veriler toplanabilir ve anne babalarla toplumsal cinsiyet kalıp yargılarına yönelik mülakatlar gerçekleştirilerek bu konudaki görüşleri alınabilir. Ayrıca çocukların oyunlarının toplumsal cinsiyet kalıp yargıları$\mathrm{n}$ içerip içermediğine yönelik deneysel ve karma desenli araştırmalar yapılabilir.

\section{Kaynakça}

Akar, T., Aksoy, B. (2018). Çocukların anne babalarına yönelik algılarının toplumsal cinsiyet bağlamında incelenmesi. Eğitim Bilimleri Dergisi, 9(1), 31-46.

Altınova, H. H. ve Duyan, V. (2013). Toplumsal cinsiyet algısı ölçeğinin geçerlik güvenirlik çalışması. Toplum ve Sosyal Hizmet, 24(2), 9-22.

Artan, İ., Saranlı A. G., Alkan Ersoy, Ö., Okutan, N. Ş., Özkızıklı, S. ve Özoran, B. A. (Ed.). (2017). Cinsel gelişim ve eğitim. Ankara: Hedef Yayıncılık ve Mühendislik.

Ata Doğan, S., Atış Akyol, N., Güney Karaman, N. (2018). Beş yaş çocuklarının cinsiyet kalıp yargı düzeyleri ve evdeki cinsiyet rollerine ilişkin görüşleri. Gazi Eğitim Bilimleri Dergisi, 4(3), 53-65. doi: 10.30855/gebd.2018.04.03.004

Aytekin, Ç., Artan, İ., Bencik Kangal, S., Çalışandemir, F., Özkızıklı, S. (2016). Çocukların anne-babalarına yönelik algılarının incelenmesi. Mehmet Akif Ersoy Üniversitesi Eğitim Fakültesi Dergisi, 38, 168-188.

Bağçeli Kahraman, P. ve Arabacıoğlu, B. (2018). Çocukların anne babalarına yönelik algıları ile anne-çocuk etkileşiminin cinsiyet rolleri açısından incelenmesi Türkiye Sosyal Araştırmalar Dergisi, [Özel Sayı], 1-16. 
Bağçeli Kahraman, P., Başal, H. A. (2011). Anne eğitim düzeyine göre çocukların cinsiyet kalıpyargıları ile oyun ve oyuncak tercihleri. e-Journal of New World Sciences Academy Education Sciences, 6(1), 1335-1357.

Baran, G. (1995). Ankara'da bulunan çocuk yuvalarında kalan 7-11 yaş grubu çocuklarda cinsiyet rolleri ve cinsiyet özellikleri kalıpyargllarının gelişimi (Yayımlanmamış Doktora Tezi). Ankara Üniversitesi, Fen Bilimleri Enstitüsü, Ankara.

Bayramoğlu, L. (2015). Okul öncesi dönem çocuklarının cinsiyet rollerine ilişkin algılarının incelenmesi (Yayımlanmış Yüksek Lisans Tezi). Doğu Akdeniz Üniversitesi, Gazimağusa, Kuzey Kıbrıs Türk Cumhuriyeti.

Bee, H. ve Boyd, D. (Ed.). (2009). Çocuk gelişim psikolojisi (O. Gündüz, Çev. Ed. ). İstanbul: Kaknüs Yayınları.

Creswell, J. W. (Ed.). (2016). Araştırma deseni: Nitel, nicel ve karma yöntem yaklaşımları (3. baskı) (S. B. Demir, Çev. Ed. ). Ankara: Eğiten Kitap.

Creswell, J. W. ve Creswell, J. D. (Ed.). (2018). Research design: Qualitative, quantitative, and mixed methods approaches (4th ed.). California, USA: Sage Publications.

Creswell, J. W., Hanson, W. E., Clark Plano, V.L. ve Morales, A. (2007). Qualitativeresearch designs: Selection and implementation. The Counseling Psychologist, 35(2), 236-264. Erişim adresi: https://doi.org/10.1177/0011000006287390

Çarkoğlu, A. ve Kalaycığlu, E. (2013). Türkiye'de aile, iş ve toplumsal cinsiyet (2019, Temmuz 20). Erişim adresi: http://kasaum.ankara.edu.tr/ files/2013/11/turkiyedeaileisvetoplumsalcinsiyetraporu2.pdf

Çiftçi, M. A., Özgün, Ö. (2011). Okul öncesi dönemdeki çocukların oyuncak tercihlerinin ve akran etkileşimlerinin ebeveyn cinsiyet rolleri algısı bağlamında incelenmesi. e-Journal of New World Sciences Academy Education Sciences, 6(3), 2246-2261.

Dedeoğlu, S. (2000). Toplumsal cinsiyet rolleri açısından Türkiye'de aile ve kadın emeği. Toplum ve Bilim, 86(3), 139-170.

Dilek, A. (2014). 4-6 yaş çocuk öykülerindeki kadın kahramanların mesleksel analizi. Journal of Qafqaz University - Philology and Pedagogy, 2(1), 94-102.

Ex, C. T., ve Janssens, J. M. (2000). Young females' images of motherhood. Sex Roles, 43(11-12), 865-890.

Günay, G. ve Bener, Ö. (2011). Kadınların toplumsal cinsiyet rolleri çerçevesinde aile içi yaşamı algılama biçimleri. Türkiye Sosyal Araştırmalar Dergisi, 153, 157-171.

Güney, O. (2012). 5-6 yaş çocuklarında algılanan cinsiyet kalıpyargllarına ilişkin ebeveyn beklentileri ile oyuncak tercihleri arasındaki ilişki (Yayımlanmış Yüksek Lisans Tezi). Maltepe Üniversitesi, Sosyal Bilimler Enstitüsü, İstanbul. 
Gürşimşek, I. ve Günay Doğan, V. (2005). Çocukların kitaplarında cinsiyet rollerinin işlenişinde kullanılan dilsel ve dildışı göstergelerin değerlendirilmesi. Dokuz Eylül Üniversitesi Buca Eğitim Fakültesi Dergisi, 18, 53-63.

İmamoğlu, O. (2012). Değişen dünyada değişen aile-içi roller. Kadın Araştırmaları Dergisi, 1, 58-68. Erişim adresi: https://dergipark.org.tr/tr/pub/iukad/ issue/729/7875

Karabekmez, S., Yıldırım, G., Özyılmaz Akamca, G., Ellez, A. M. ve Bulut Üner, A. N. (2018). Okul öncesi dönem çocuklarının mesleklere yönelik toplumsal cinsiyet algılarının incelenmesi. Bilim, Eğitim, Sanat ve Teknoloji Dergisi, 2(1), 52-70.

Şıvgın, N. (2015). Cinsiyet rolleri eğitim etkinliklerinin anasınıfina devam eden 60-72 aylık çocukların toplumsal cinsiyet kalıpyargllarına etkisinin incelenmesi (Yayımlanmamış Doktora Tezi). Gazi Üniversitesi, Eğitim Bilimleri Enstitüsü, Ankara.

Yağan Güder, S. (2014). Okul öncesi dönemdeki çocukların toplumsal cinsiyet algılarının incelenmesi (Yayımlanmış Yüksek Lisans/Doktora Tezi). Hacettepe Üniversitesi, Ankara.

Yağan Güder, S., Ay, A., Saray, F., Kılıç, İ. (2017). Okul öncesi dönem çocuklarının izledikleri çizgi filmlerin toplumsal cinsiyet kalıp yargıları açısından incelenmesi: Niloya örneği. Eğitimde Nitel Araştırmalar Dergisi, 5(2), 96-111.

Yağan Güder, S., Güler Yıldız, T. (2016). Okul öncesi dönemdeki çocukların toplumsal cinsiyet algılarında ailenin rolü. Hacettepe Üniversitesi Eğitim Fakültesi Dergisi, 31(2), 1-23. doi: 10.16986/HUJE.2016016429

Yıldırım, A. ve Şimşek, H. (Ed.). (2016). Sosyal bilimlerde nitel araştırma yöntemleri. Ankara: Seçkin Yayıncılık. 
Extended Abstract

\section{Analysis of the Views of Preschool Children Regarding Their Mothers' Roles Inside and Outside Home in Terms of Social Gender}

Gizem ÖZER, Corresponding Author, Assistant Professor.

Zonguldak Bülent Ecevit University, Ereğli Faculty of Education, Turkey.

gizemozer@beun.edu.tr

http://orcid.org/0000-0002-3560-3632

Pembe Buse KESER, Preschool Teacher.

Republic of Turkey Ministry of National Education, Turkey.

buseksr10@gmail.com

http://orcid.org/0000-0003-4500-8711

Article Type: Research Article

https://doi.org/10.34234/ded.679593

Received Date: 21.01 .2020

Accepted Date: 07.05 .2020

Published Date: 25.06.2020

\section{Introduction}

The characteristics of being men and women acquired through the socialization process are expressed as social gender (Altınova and Duyan, 2013). Social gender varies with the concept of gender by its social aspect, while gender emphasizes the biological characteristic, social gender emphasizes the societal characteristic. With the conceptual development of social gender, stereotypes about this concept have come into existence. Stereotypes can be defined as beliefs about the suitability of various behaviors for women and men (Güney, 2012). However, when the formation and general course of these stereotypes are monitored, it is seen that they are exacerbating gender inequality to the detriment women. Especially in our country, it can be noticed that there are a 
number of accepted social gender stereotypes about women such as "works/ behaviors that must be done/acted by women" in household work.

In some studies, it has been observed that children also use such stereotyped formulaic expressions. In the studies of Bağçeli Kahraman and Arabacıoğlu (2018), it was observed that the majority of children responded to the question in relation to what their mothers do, as "she cooks" in the first rank and "she cleans" in the second rank. However, when the same question was asked about their fathers, it was stated that they responded as "he goes to work" in the first rank and "he earns money" in the following rank. Similarly, in the research of Akar and Aksoy (2018), it was stated that the children responded to the question about what their mothers do at home as; "cleaning" and "cooking". Depending on these and similar studies, it can be said that there are no practice based on the equality for the responsibility of housework between mother and father. Günay and Bener (2011) stated that from the traditional point of view, works and responsibilities in the family are shared in an unequal way by discrimination based on gender. The views of children who are members of the family can reveal significant signs about the role of the woman, in other word their mother in the family. Consequently, in this study, it is aimed to interpret the data obtained in terms of social gender by examining the behavior of mothers inside and outside the home within the scope of the opinions of children. The sub-survey questions were determined as "what mothers do inside the home" and "what they do outside the home".

\section{Method}

Qualitative research method was used in the study. Among the qualitative research methods, the case study was used and semi-structured interviews were conducted with children. Content analysis was used in the analysis of the data obtained. Content analysis; includes the process of naming meaningful sections within the data; data of similar nature are gathered and interpreted in line with certain concepts and themes (Yıldırım and Şimşek, 2016).

\section{Study Group}

Purposeful sampling method was used in the research. The study group is children who attend the kindergarten of a primary school located in the Karadeniz Ereğli Township of Zonguldak Province for the 2018 and 2019 academic year 
fall semester. The study group consists of 20 children, three of whom are four years old, fifteen of whom are five years old and two of whom are six years old. Ten of the children are boys and ten are girls.

\section{Data Collection Process}

The data was collected through semi-structured interview questions. The researcher asked children two different questions "What does your mother do at home?" and "What does your mother do outside?" and requested the children to draw two pictures about these questions and describe the pictures they drew. The researcher recorded the children's statements by writing them. The pictures drawn by the children were not subjected to any picture analysis and were visually included in the study to support the verbal data obtained.

\section{Analysis of the Data}

The data collected was analyzed by content analysis method. The researcher first coded the data obtained from the interviews in accordance with the pictures drawn by the children, and then reached certain categories and themes from these codes. The data was analyzed in two parts. Initially, the interview records the responses to"What does your mother do at home?" and then the interview records responses to "What does your mother do outside?" were analyzed.

\section{Validity and Reliability Measures}

One of the methods used to ensure validity and reliability in qualitative research is triangulation. In this study, children's drawings were used to support verbal interview records of children to contribute to the triangulation. The technique of external controller/expert opinion that is another recommended method for ensuring validity and reliability, was also used in this study. In order to achieve this, opinions of a faculty member who studied on qualitative research were asked. Direct citations in qualitative research on validity and reliability also contribute to internal reliability processes (LeCompte and Goetz, 1982; as cited in Yıldırım and Şimşek, 2016). In this study, the statements of the children are presented with quotations containing the exact words they said directly in the findings section. 


\section{Findings and Interpretation}

\section{Findings (Codes) For The Section "What Your Mother Does at Home?"}

In the code obtained as a result of the content analysis, the researcher has initially reached the codes of "she cooks", "she tidies up the house", "she makes up the bed", "she does cleaning", "she sweeps the house", "she washes the dishes", "she does the laundry", "she watches TV" form both girls and boys. In addition to the codes obtained above for girls and boys, those who are not common in the codes of girls and boys are "she prepares food for the cat" and "she knits" codes for the girls. Other codes of boys that are not common with girls are "she wipes the floor", "she clears toys away", "she paints", "she watches cartoons". When the first obtained codes are examined, it is felt that the mothers do "cooking" and "cleaning" work in the house are the most common answers. For example, the boy KZ responded as "she cooks, she washes dishes, she wipes up floors when they are dirty, she cleans walls, she does laundry."

\section{Findings (Codes) for the Section "What Does Your Mother Do Out- side?"}

In the initial codes obtained as a result of the content analysis, the researcher has reached the codes of "she does nothing", "she goes to the bazaar", "she buys food", "she lets me play", "she takes me to the park", "she takes me a trip", "she takes a walk", "she buys clothes" form both girls and boys. In addition to the codes obtained above for girls and boys, the responses that are not common in the codes of girls are "she sweeps outside", "she cleans the stairs", "she washes the carpet", "she tidies up the outside", "she waters the flowers", "she goes to work", "she goes to the cinema", "she goes out with friends", "she talks to friends" codes. Other codes of boys that are not common with girls are as "she waters the garden", "she takes me to school", "she makes a snowman", "she does cleaning in downstairs", "she goes to the doctor", "she chats", "she rests", "she goes on visit" and "she buys milk".

When the initial codes are examined, it is observed that mothers are active with respect to the outdoor childcare and social activity, as well as concerning with outdoor responsibilities. But at the same time, it is understood from the expressions of the children that the mothers do cleaning at the time they spend out- 
side. The children's "she does nothing" statement is also noteworthy. The girl Y, who is in the context of the code of "she tidies up the outside", expressed herself when she draws the picture as: "I draw stairs too. She cleans up the stairs. She goes to tidy up outdoor. I'll draw sand and also a broom." (Pronounced in local colloquial expression). The girl Z, who is in the context of the code "she does nothing", responded as, "Well, my mother doesn't go anywhere. She just sits at home." The boy in the same code YÇ told, "My mother does not do anything when she goes out."

\section{Findings (Categories) For The Section "What Does Your Mother Do at Home?"}

By the repeated readings of the codes, the researcher realized that there were similarities among the certain codes and reached various categories in this direction. The categories obtained for the question of "What does your mother do at home?" are "she cooks", "she tidies up the house", "she does indoor cleaning", "she watches TV", "she knits", "she prepares food for the cat", "she irons" and "she takes care of children".

\section{Findings (Gategories) For "What Your Mother Does Outside?" Section}

The researcher reached more grouped categories in line with the codes he/she read repeatedly, similar to the procedures he did in the previous section. The categories obtained from girls and boys for the question of "what does your mother do outside?" are as "she does outdoor cleaning", "she waters plants", "she takes care of children", "she does nothing", "she goes to bazaar", "she buys food", "she buys cloth", "she has fun", "she spends time with friends", "she tidies up the outside", "she goes to work", "she goes to the doctor" and "she buys milk".

\section{Findings (Themes) for "What Your Mother Does at Home?" Section}

Initially, themes were attained from the categories, then these themes were reviewed and the themes were rearranged and put into final form. Accordingly, those that include the sub-themes which mothers make at home such as "cooking", "organizing", "cleaning" have been rearranged as "keep house", those that include sub-themes such as "living creature care" and "caring for children" have been rearranged as "interest in others" and that includes sub-theme such as "doing activities at home" has been rearranged as "self-interest". 


\section{Findings (Themes) for "What Does Your Mother Do Outside?" Sec- tion}

The initial themes related with the section of "what the mother does outside" were reviewed and the themes were rearranged and put into final form in the same way as the in the previous section. Consequently, the themes of "cleaning" and "organizing" have formed the theme of "tidy outdoor", the themes of "going to work", "care of any creature", "going to the doctor", "shopping" have formed the theme of "responsibility", the theme of "social activity" has formed the theme of "positive self-interest", the theme of "not doing anything" has formed the theme of "negative self-interest" and the theme of "caring for children" has formed the theme of "interest to children".

\section{Discussion and Recommendations}

One noteworthy point in the themes obtained is that the views on cooking and cleaning included in the theme of "keep house " are included as a maternal behavior that children often express. This indicates that children adopt the mother's social gender identity in the form of cooking and cleaning or reflect the reality of what happens at home as it is. Considering that they reflect the reality of the house, it can be interpreted that the woman takes an active role in cooking and cleaning in the house, while the man remains in the background in these activities. Similarly, in the study done by Akar and Aksoy (2018) it is observed that early and middle childhood children portray their mothers as cooking and cleaning figure in the kitchen. In another study, based on the data obtained from the analysis of the views of 5-year-old children about gender stereotypes and gender roles at home, it was confirmed that they indicate that their mothers played a more active role in similar tasks such as cooking, setting and cleaning the table (Ata Doğan, Atış Akyol and Güney Karaman, 2018). In the study carried out by Bağçeli Kahraman and Arabacioğlu (2018) regarding the question of "What does the mother do", once again in parallel with our study, it is seen that the children responded as mother cooks, cleans, takes care of children, does housework, care for her children.

In our study, it was noticed that children portrayed their mothers as who do the cleaning at home, as well as outdoor, and a theme was attained in this direction (tidying outside). The children's indication that their mothers' presentation of tyding outside behavior is similar to their keep house behavior can be an 
expression of how children perceive their mothers' outside activitiy in a similar way to the ones at home. Or it could also be a testament that children are reflecting the reality to us and that women can't "escape" from doing cleaning activities even outside the home.

In a study by Fulcher et al. (2007), it was determined that the roles shared between spouses within the home affect the social gender attitudes of children (As cited in; Yağan Güder and Güler Yıldız, 2016). If we take into consideration that children are observational learners in preschool period, it is recommended that mothers and fathers should be role models for equality as much as possible in the context of their home and outside responsibilities, and they should try to maintain a balanced role distribution between the two sexes for themselves and for their children and raise individuals who are sensitive to gender equality in order not to produce social gender inequality. 